Article

\title{
Approach to a Project Framework in the Environment of Sustainability and Corporate Social Responsibility (CSR): Case Study of a Training Proposal to a Group of Students in a Higher Education Institution
}

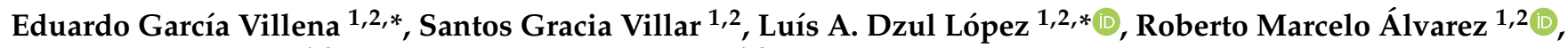 \\ Irene Delgado Noya ${ }^{1,3}$ and Juan Luís Vidal Mazón ${ }^{1,3}$ \\ 1 Higher Polytechnic School/Industrial Organization Engineering, Universidad Europea del \\ Atlántico (UNEATLANTICO), Isabel Torres 21, 39011 Santander, Spain; santos.gracia@uneatlantico.es (S.G.V.); \\ roberto.alvarez@uneatlantico.es (R.M.Á.); irene.delgado@uneatlantico.es (I.D.N.); \\ juanluis.vidal@uneatlantico.es (J.L.V.M.) \\ 2 Department of Project Management, Universidad Internacional Iberoamericana (UNINI-MX), \\ Campeche 24560, Mexico \\ 3 Project Department, Universidade Internacional do Cuanza, Municipio do Kuito, Bairro Sede (6335.09 km), \\ Bié, Angola \\ * Correspondence: eduardo.garcia@uneatlantico.es (E.G.V.); luis.dzul@unini.edu.mx (L.A.D.L.)
}

check for updates

Citation: García Villena, E.; Gracia Villar, S.; Dzul López, L.A.; Álvarez, R.M.; Delgado Noya, I.; Luís Vidal Mazón, J. Approach to a Project Framework in the Environment of Sustainability and Corporate Social Responsibility (CSR): Case Study of a Training Proposal to a Group of Students in a Higher Education Institution. Sustainability 2021, 13, 10880. https://doi.org/10.3390/ su131910880

Academic Editor: Roberta Costa

Received: 18 August 2021

Accepted: 27 September 2021

Published: 30 September 2021

Publisher's Note: MDPI stays neutral with regard to jurisdictional claims in published maps and institutional affiliations.

Copyright: (c) 2021 by the authors. Licensee MDPI, Basel, Switzerland. This article is an open access article distributed under the terms and conditions of the Creative Commons Attribution (CC BY) license (https:/ / creativecommons.org/licenses/by/ $4.0 /)$.
Abstract: The purpose of this research was to plan an approach to a project framework that integrated a model for sustainability and CSR, with the process groups of the Project Management Body of Knowledge $\left(\mathrm{PMBOK}^{\circledR}\right)$ standard, in its application to the training of a group of students in Project Design, Management, and Evaluation. The integration was justified by the scarce explicit references to sustainability and CSR found in traditional project management guidelines, norms, and standards. The new framework was used to structure a Sustainability Management Plan, which made it possible to incorporate sustainability criteria throughout the life cycle of the training project. The training proposal in Project Design, Management, and Evaluation was chosen, among several alternatives, by a multi-criteria selection process (fuzzy AHP) in the context of project scope management. The results reveal a great heterogeneity among the models and the lack of a base of key indicators in sustainability and CSR measurement tools as well as of explicit references to sustainability in project management standards. It is therefore necessary to develop a Sustainability Management Plan that can be introduced in the Project Management Plan and thus influence the strategic and operational guidelines of the Institution.

Keywords: $\mathrm{PMBOK}^{\circledR}$; CSR; Project Management Plan; sustainability; Project Design; Management and Evaluation; fuzzy AHP

\section{Introduction}

\subsection{The Change in the Sustainability Paradigm}

Since the emergence of the concept of sustainability in 1987 and as a result of the report "Our Common Future," which defined sustainable development as that which "guarantees the needs of the present without compromising the ability of future generations to meet their own needs" [1], there has been a multitude of definitions, uses, and nuances of the term, influenced by the policies and social and academic movements that took place during the last third of the 20th century [2].

In spite of all these meanings, the origin of sustainability should be placed at first in the environmental context [3] as a response to the impacts derived from the intensive use of natural resources in productive activities. Subsequently, the term took on an economic dimension from the business point of view, making growth compatible with the environment, thus creating value for different stakeholders [4]. 
CSR was originally conceived from a philanthropic point of view but gradually acquired a more strategic and integral character [3]. Thus, both terms-sustainability and CSR - converge in assessing the impact of the actions of business activities on society.

However, as is clear from the definition of sustainable development, sustainability has a temporal connotation of the future that involves going beyond the here and now of CSR [5], integrating the concept through the corporate and strategic culture of the organization and making it endure over time [6].

Figure 1 is enlightening in relation to the differences between CSR and sustainability. While the former deals with present and past actions (striped or integral area) in the form of temporal reports about the company's image, sustainability is the slope of the straight line (derivative) that points to the future trend.

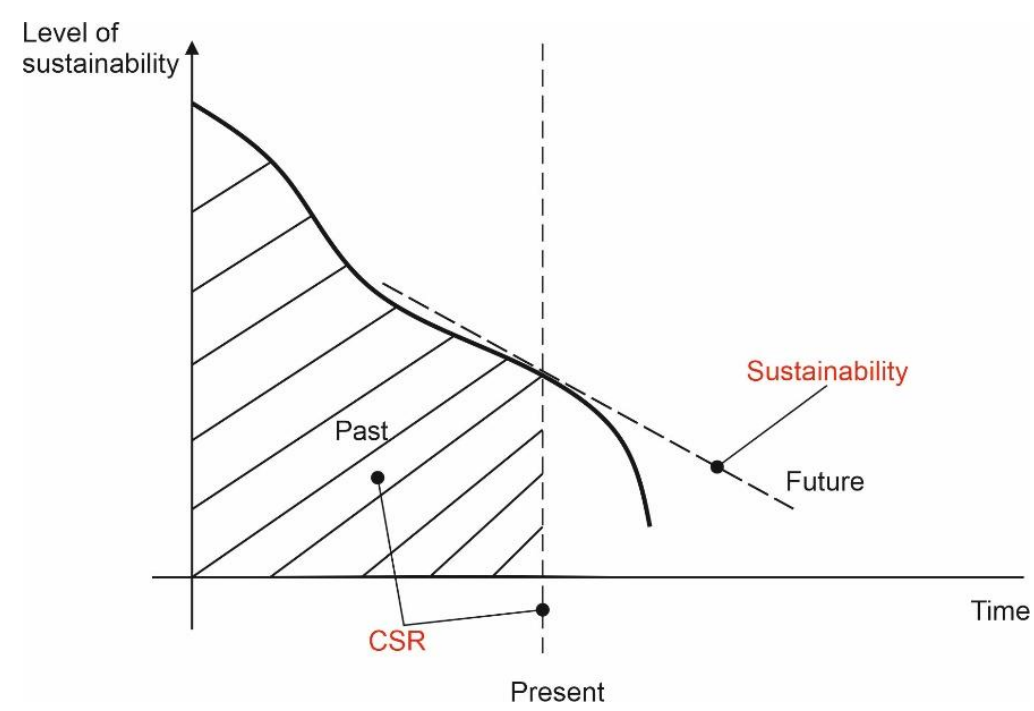

Figure 1. Differences between sustainability and Corporate Social Responsibility (CSR). Note: Own elaboration.

This has been the case so much so that, in recent years, the obsolescence of the CSR has become evident, understood as a reactive and secondary process almost exclusively identified with philanthropy and independent of the company's main activities [5,7].

In effect, organizations can no longer limit themselves to achieving an acceptable balance between economic, social, and environmental balance but must encourage the evolution towards new models more in line with the current global situation [8]. Some of the advantages in this regard are [9]:

- An improvement of the organization's image.

- Achievement of competitive advantages.

- Reduction of emissions, waste, and use of renewable energies.

- A higher return on investment ratio.

- Lower staff turnover rate, better integration of employees, labor equity measures, family reconciliation, etc.

However, the implementation of a model for sustainability involves numerous difficulties [7]: resistance to change, lack of knowledge to overcome the environmental origin of sustainability, breaking with the philanthropic stereotype of CSR, and the construction of a business model of sustainability (business case). Other authors add political and financial fear when applying sustainability and lack of leadership and management [9].

It is in this context that the important role of education is highlighted so that, on the one hand, individuals and communities can adapt to environmental, social, and economic changes and, on the other hand, make their contribution to the very difficult task of changing our mentality and our worldview [10]. 
In this way, education, through project management processes [11], can reverse and change objectives for the sake of sustainability, which directly affects the strategic guidelines of the organization, delivering business value [12,13].

The research problem lies in the fact that project management standards and norms do not include indicators and measurement criteria for sustainability.

Thus, having stated the problem, the research question is as follows:

- How should a Sustainability Management Plan be implemented in a project structure to plan a proposal for sustainable student training?

This integration must take place at all stages of the life cycle and at all levels: project, process, and product [14]. These levels, which are interdependent, are constituted by indicators or measurement criteria that can reverse and change the objectives in favor of sustainability, directly impacting the strategic guidelines of the organization, to align with the objectives of society, and adapt to the changes that occur continuously $[15,16]$.

The research sub-questions would be as follows:

- What are the fundamental differences between CSR and sustainability?

- Is it possible to develop a sustainable project framework based on equivalencies between standards for the planning of a student training proposal?

- Why is it necessary to implement sustainability indicators or measurement criteria at all phases and levels of project, process, and product life-cycle analysis?

- Is it appropriate to plan a training program by breaking it down into work packages within a project structure?

For the authors of this research, it became especially relevant to contribute to the definition of a model for sustainability in the organization that prioritized a series of environmental, economic, and social aspects and had an impact on the delivery of value to the local community in a transparent, fair, and ethical manner. This model was instrumented in a series of sustainable measurement criteria and matched with a project structure (processes) in order to identify gaps and establish a Project Management Plan that included a Sustainability Management Plan applicable to the development of the planning of a sustainable training proposal for students (product).

The scope of planning for a sustainable training proposal within the project, contained in the Sustainability Management Plan, was broken down into several first-level work packages, which in turn were divided into second-level work packages, and which served as the basis for determining the project deliverables, the description of which includes the indicators or measurement criteria for sustainability.

\subsection{Models and Instruments for Organizational Sustainability}

Currently, sustainability involves a medium- and long-term vision [6] based on the "Triple Bottom Line" (TBL) theory, which makes it possible to evaluate, from the point of view of stakeholders, what value is being created, distinguishing in the organization's income statement three areas: economic, social, and environmental (Figure 2).

It is therefore necessary to translate this model into something less abstract, which can be instrumentalized and introduced within organizations in general and in the field of project management processes in particular. 


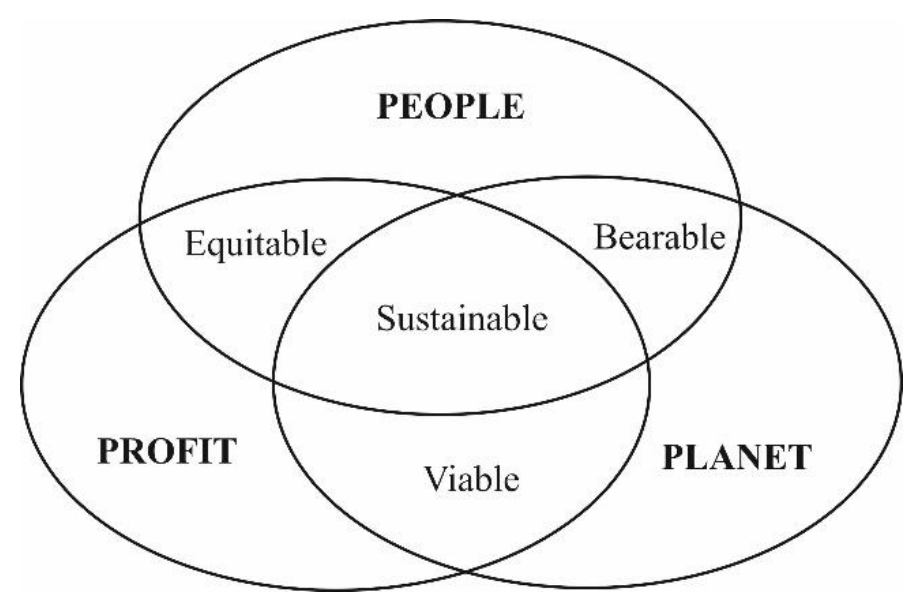

Figure 2. The Triple Bottom Line (TBL). Note: Own elaboration based on Tasdemir et al. [17].

This process, called "operationalization of variables," is based on theoretical, conceptual, and operational definitions to progressively reduce the degree of abstraction of the variables [18], as illustrated in Figure 3.

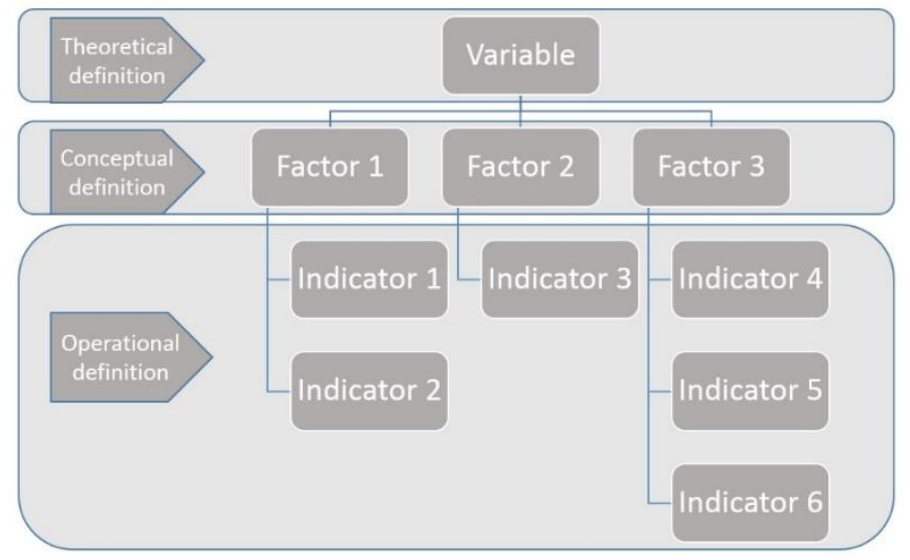

Figure 3. Simplified process of operationalization of a variable. Note: Adapted from Alva [19].

However, current sustainability models applied to organizations are incomplete and generally respond to sporadic and isolated marketing actions, which do not affect the overall strategy of the organization $[20,21]$.

In this context, the social and environmental dimensions are rarely taken into account in the business strategies and practices of organizations [13] since what is maximized is economic profit [22].

On the other hand, the lack of consensus on the guiding principles of social responsibility and sustainability has determined that to date there is no agreement on how it should be defined or measured, basically due to the difficulty of quantifying the environmental and social aspects in relation to the economic aspect [5,7,23,24].

This problem has meant, especially in the last decade [25], the instrumentalization of a large number and variety of models on sustainability and corporate social responsibility, which have added more confusion and dispersion to the existing ones.

Table 1 shows some instruments for implementation and/or performance measurement, mostly based on the principles of corporate social responsibility, such as codes of ethics and conduct, management standards, social responsibility reports, and ethical stock market indexes. 
Table 1. Business Sustainability Tools and Instruments.

\begin{tabular}{|c|c|c|}
\hline Scope & Description & Tools and Instruments \\
\hline Codes of ethics & $\begin{array}{l}\text { Statements of values and principles of conduct that } \\
\text { regulate the relationships among the members of } \\
\text { the institution and with the outside world. }\end{array}$ & \multirow[b]{2}{*}{$\begin{array}{ll}\text { - } & \text { MNE }^{1} \text { Declaration } \\
\text { - } & \text { OECD Guidelines } \\
\text { - } & \text { United Nations Global Compact } \\
\text { Sullivan's Global Principles }\end{array}$} \\
\hline Codes of conduct & $\begin{array}{l}\text { Document that describes the basic rights and } \\
\text { minimum standards (respect for human rights and } \\
\text { labor rights, among others) that an institution } \\
\text { declares to be committed to respect in its relations } \\
\text { with its workers, the community, and } \\
\text { the environment. }\end{array}$ & \\
\hline Management system standards & $\begin{array}{l}\text { Enable the institution to have a clear vision of the } \\
\text { impact of its activities in the social and } \\
\text { environmental fields for the continuous } \\
\text { improvement of its processes. }\end{array}$ & $\begin{array}{ll}\text { - } & \text { ISO } 14001 \\
\text { - } & \text { EMAS } \\
\text { - } & \text { ISO } 26000 \\
\text { - } & \text { SGE } 21 \\
\text { - } & \text { SA } 8000, \text { AA } 1000 \ldots\end{array}$ \\
\hline
\end{tabular}

Social responsibility reports

Socially Responsible Investment (SRI)
A report prepared and published by the company or institution measuring its economic, social, and environmental performance of its activities and communicated to the company's stakeholders.

SRI brings together all the elements that consist of integrating extra-financial, environmental, and social criteria in investment decisions.
- $\quad$ Global Reporting Initiative (GRI)

- $\quad$ Dow Jones Sustainability Group Indexes (DJSI) of N.Y.

- $\quad$ London Footsie for Good (FTSE4Good)

- $\quad$ MSCI ESG, Morgan Stanley Capital International

Note: ${ }^{1}$ Tripartite Declaration of Principles concerning Multinational Enterprises and Social Policy. Modified from [26].

Most of these instruments, designed to achieve business sustainability, are based on the TBL theory and are aimed at alleviating existing problems, i.e., they are complementary to the company's activities, without proposing a change from within the business management model [5].

In 2010, the International Organization of Standardization (ISO) published the ISO 26000 standard "Guidelines on Social Responsibility" [27], with the aim of harmonizing all standards, guidelines, and models on ethics and social responsibility, focusing on the integration of certifiable standards on quality, environment, and risk prevention, among others, which would allow the optimization of resources and the satisfaction of the current and future needs of all stakeholders related to the organization. It contains core subjects such a governance, human rights, environment, community, etc. The fact that it is not certifiable, its excessive complexity and extension, the lack of resources for its application, its focus on large companies, and the lack of dissemination, among other issues, have prevented its widespread implementation [28].

\subsection{Sustainability and CSR in Project Management Methodologies and Standards}

Project management methodologies and standards began during the 1960s, and like the models and instruments for sustainability, different management approaches were developed.

In this context, traditional approaches manage a waterfall project with well-defined stages and a linear life cycle. They are based on the "triple constraint" of scope-time-cost and require precise stakeholder communications and minimal changes during the life of a project. The best known methodologies are those of Waterfall, Critical Path Method (CPM), and Critical Chain Project Management (CCPM).

For its part, the concept of agile management (Agile Methodologies) overcomes the limitations of traditional management by presenting a structure based on incremental and iterative work, incorporating greater flexibility in the face of frequent changes and greater 
cooperation and communication with stakeholders [29]. Some methodologies in this regard are Scrum, Kanban, and Adaptive Project Framework (APF). There are methodologies that incorporate sustainability into the project, such as PRISM (Projects Integrating Sustainable Methods), which incorporates governance, environmental, economic, social, and technical factors from a set of best practices collected in different ISO standards for quality, environment, energy, project management, and corporate social responsibility [9]. On the other hand, the P5 Strategy (People, Planet, Profit, Process, Products) is an extension of the PRISM methodology that incorporates sustainability in processes and products [30].

In relation to generic standards, which will be the subject of this research, because they have greater relevance and acceptability in project management, they can be focused by processes or competencies. Among the former, there is the 6th edition of the PMBOK ${ }^{\circledR}$ Guide [31] and the standard "ISO 21500:2012 Guidance on project management" [32]. In contrast, the "ICB4 Competence Baseline" is aimed at defining the work of project management personnel and serves as a basis for the assessment of their competencies [33]. These two types of standards - process approach and competency-based approach—should not be perceived as similar or as opposites but as complementary [34]. As mentioned above, CSR represents the here and now, i.e., actions taking place in the present. In this sense, it refers to processes of the planning phase, such as the identification of stakeholders, legal, and other requirements to which the organization subscribes and environmental impacts, hazards, etc., while sustainability represents the medium and long term, where considerations, such as the life-cycle analysis of the project, the process itself and the product [14], the linkage of the project to the services of the local community, the interrelation of the project with other projects, and finally the orientation to sustainable production and consumption, would have a place [6]. Morfaw [15] defined seven characteristics that a sustainable project must meet: adaptability, audit ability, implement ability, scalability, extensibility, maintainability, and manageability. All these characteristics, with their variations, are integrated within the constraints of scope, time, cost, and quality, which form the vertices of the tetrahedron in Figure 4.

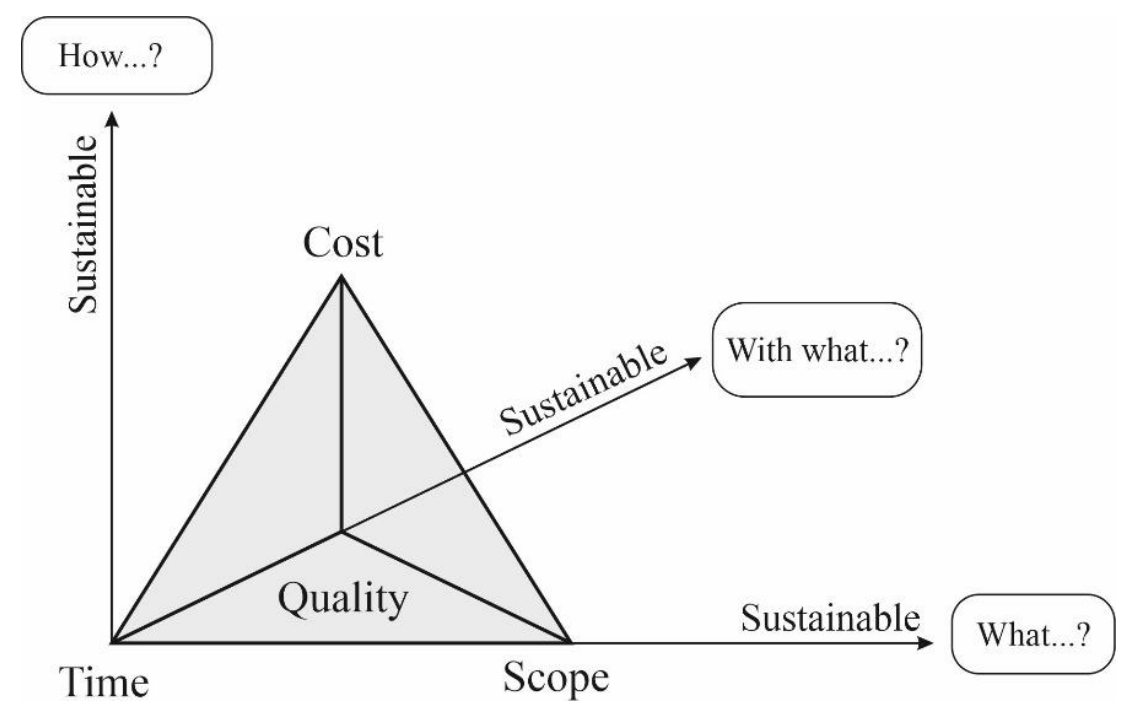

Figure 4. Sustainability limits of a project. Note: Own elaboration.

For their part, Silvius et al. [13] defined six principles of sustainability in projects, which refer to concepts such as local or global orientation in the short and long term; the need for harmonization of social, economic, and environmental interests; transparency and accountability; personal and ethical values; and finally to the consumption of income to the detriment of capital.

Toljaga [29] considered that sustainability principles do not influence all process groups equally. In this sense, they showed that all the mentioned aspects have an impact 
on the initiation, planning, and execution of the process groups but not on the monitoring and control and closure stages (Figure 5).

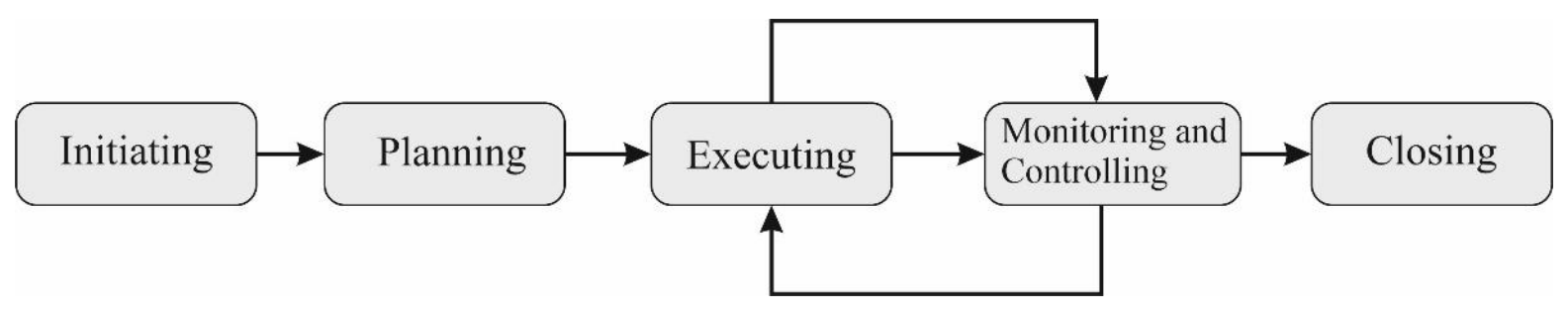

Figure 5. Project life cycle. Note: Own elaboration.

This approach to sustainability applied to projects is referred to by Piza-Flores et al. [35], who considered the inclusion of a sustainability model as one of the guiding principles to be included holistically in global standards within the life cycle of a project, preventing it from becoming a complementary and disjointed activity with the raison d'être of the project and with the strategic design of the organization [6].

However, due to the difficulties mentioned above, it has only been in recent years that sustainability has begun to be incorporated into project management.

In fact, there are works, such as Okland [36], which collect the explicit absence of the term in standards or project standards, such as PMBOK ${ }^{\circledR}$, PRINCE2, or IPMA ICB3 ${ }^{\circledR}[6,37]$.

In this context, Figure 6 shows five key words related to sustainability models, which appear in the 6th and 7th editions of the PMBOK ${ }^{\circledR}$, ICB$^{\circledR}{ }^{\circledR}$-IPMA, and ISO 21500:2012 standards. It can be seen that there are no significant differences between the two versions of the $\mathrm{PMBOK}^{\circledR}$ and that, in general, there are very few explicit references to these terms in the three standards, especially in ISO 21500:2012.

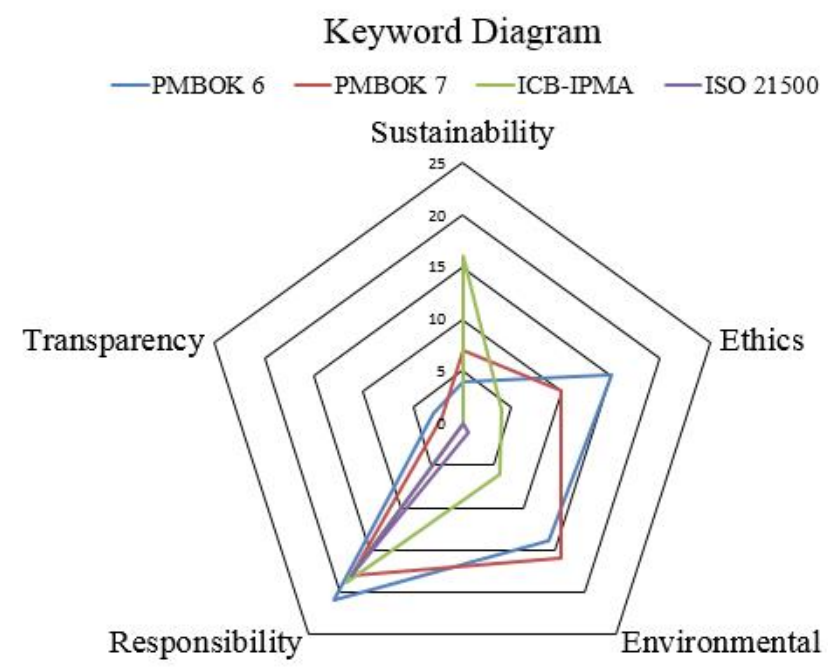

Figure 6. Posting of five keywords related to sustainability models in the $\mathrm{PMBOK}^{\circledR}$ (6th and 7th edition), ICB $4^{\circledR}{ }_{-}$IPMA, and ISO 21500:2012 project standards. Note: Own elaboration.

In the field of sustainable project manager competencies, Toljaga et al. [29] and Sabini et al. [38] confirmed that there is a growing number of studies on the subject but that it is still significantly less than the publications that can be found on traditional project manager competency topics.

Therefore, and due to the non-existence of a standard analytical framework for understanding sustainable project management, further research is needed to help organizations manage their projects [39].

Finally, it is worth mentioning that the objective of this section responded to the need to know the current status of the work and degree of involvement of sustainability 
principles in traditional project methodologies and standards. The word count study, although indicative, was revealing in confirming the lack of explicit involvement in this sense, which makes the possibility of integrating this type of criteria in Project Direction and Management standards more interesting.

\subsection{The $P M B O K^{\circledR}$ Standard}

The $\mathrm{PMBOK}^{\circledR}$ standard, belonging to the Project Management Institute (PMI), is a Guide that, in its 6th edition, includes 10 areas of knowledge for a total of 49 project management processes belonging to the groups initiation, planning, execution, monitoring and control, and closing.

It is not a methodology but rather aims to provide a set of best practices to "create a unique product, service, or result, through a complex process, via a temporary effort" [31].

Table 2 shows the process map proposed in the 6th edition of the PMBOK ${ }^{\circledR}$ Guide, to which must be added an "extension for sustainability" provided by the authors of this research.

Table 2. Fragment of Process Map Proposed in the 6th Edition of the PMBOK ${ }^{\circledR}$ Guide and Extension for Sustainability.

\begin{tabular}{|c|c|c|c|c|c|c|}
\hline \multirow{6}{*}{ 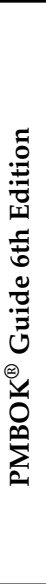 } & & \multicolumn{5}{|c|}{ Process Groups } \\
\hline & Knowledge Area & Initiating & Planning & Executing & $\begin{array}{l}\text { Monitoring and } \\
\text { Controlling }\end{array}$ & Closing \\
\hline & $\begin{array}{l}\text { 4. Project Integration } \\
\text { Management (7) }\end{array}$ & $\begin{array}{l}\text { 4.1. Develop } \\
\text { Project Charter }\end{array}$ & $\begin{array}{l}\text { 4.2. Develop Project } \\
\text { Management Plan }\end{array}$ & $\begin{array}{l}\text { 4.3. Direct and } \\
\text { Manage Project Work } \\
\text { 4.4. Manage Project } \\
\text { Knowledge }\end{array}$ & $\begin{array}{l}\text { 4.5. Monitor and } \\
\text { Control Project } \\
\text { Work } \\
\text { 4.6. Perform } \\
\text { Integrated } \\
\text { Change Control }\end{array}$ & $\begin{array}{l}\text { 4.7. Close } \\
\text { Project or Phase }\end{array}$ \\
\hline & $\begin{array}{l}\text { 5. Project Scope } \\
\text { Management (6) }\end{array}$ & & $\begin{array}{l}\text { 5.1. Plan Scope } \\
\text { Management } \\
\text { 5.2. CollectRequirements } \\
\text { 5.3. Define Scope } \\
\text { 5.4. Create WBS }\end{array}$ & & $\begin{array}{l}\text { 5.5. Validate } \\
\text { Scope } \\
\text { 5.6. Control Scope }\end{array}$ & \\
\hline & $\begin{array}{c}\text { 13. Project } \\
\text { Stakeholder } \\
\text { Management (4) }\end{array}$ & $\begin{array}{l}\text { 13.1. Identify } \\
\text { Stakeholders }\end{array}$ & $\begin{array}{l}\text { 13.2. Plan Stakeholder } \\
\text { Engagement }\end{array}$ & $\begin{array}{c}\text { 13.3. Manage } \\
\text { stakeholder Engage- } \\
\text { ment/Participation }\end{array}$ & $\begin{array}{l}\text { 13.4. Monitor } \\
\text { Stakeholder } \\
\text { Engagement }\end{array}$ & \\
\hline & $\begin{array}{l}\text { Total processes by } \\
\text { process groups }(49)\end{array}$ & 2 & 24 & 10 & 12 & 1 \\
\hline$\frac{5}{2}$ & $\begin{array}{c}\text { 14. Project } \\
\text { Sustainability } \\
\text { Management (3) }\end{array}$ & & $\begin{array}{l}\text { 14.1. Plan Sustainability } \\
\text { Management }\end{array}$ & $\begin{array}{l}\text { 14.2. Manage } \\
\text { Sustainability }\end{array}$ & $\begin{array}{l}\text { 14.3. Control } \\
\text { Sustainability }\end{array}$ & \\
\hline 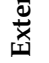 & $\begin{array}{l}\text { Total Additional } \\
\text { Processes (3) }\end{array}$ & 0 & 1 & 1 & 1 & 0 \\
\hline
\end{tabular}

Note: Adapted from PMI [31]. It can be noted that the processes always start with a verb, unlike the knowledge areas. Note that the authors of this research have added a new knowledge area related to "Project Sustainability Management."

The PMBOK ${ }^{\circledR}$ Guide, 6th edition, refers to a process as PMI [31]:

A series of project management activities that produce one or more outputs (deliverables or results at the end of the process) from one or more inputs (products or items acted upon), through the use of tools and techniques (mechanisms applied to the inputs to produce the outputs) appropriate to project management.

Figure 7 illustrates the components of a process.

According to Bravo et al. [40], the use of these processes increases the chances of success of a wide variety of project management standards and the implementation of programs complementary to the $\mathrm{PMBOK}^{\circledR}$ Guide, which contribute to the coordination of resources and improve the management of the elements of an organization, such as "The Standard for Program Management" [41] and "The Standard for Portfolio Management" [42].

Finally, we must mention a few considerations regarding the imminent release of the seventh edition of the $\mathrm{PMBOK}^{\circledR}$ Guide, which may affect this research article. Although this edition will be based on principles rather than processes, this does not mean that processbased approaches are no longer useful. In fact, project management is not understood without processes that generate outputs and deliver value. As the summary of changes in 
the Guide makes explicit: conventional approaches will remain relevant in the context of the new version [12].
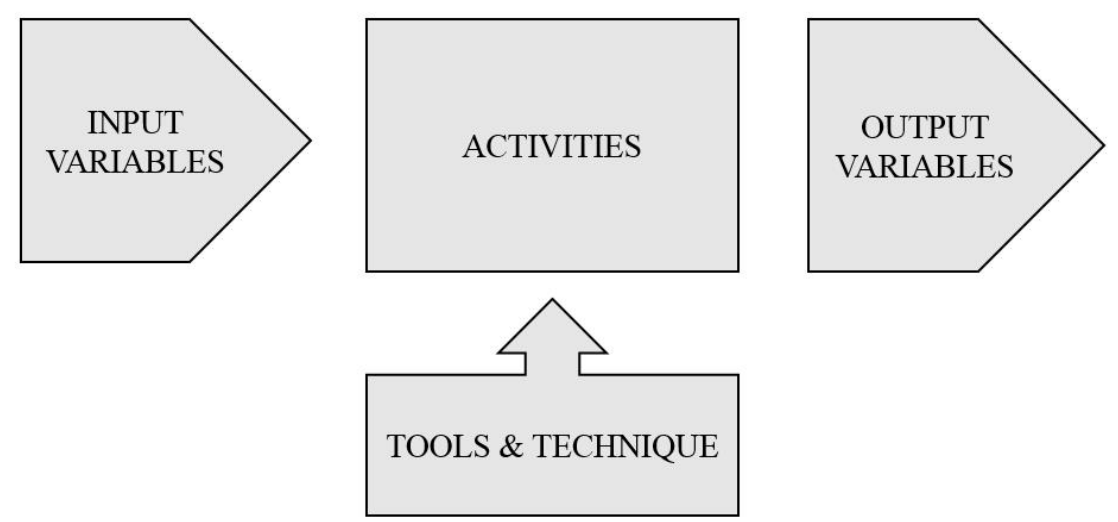

Figure 7. Components of a process. Note: Adapted from PMI [31].

\subsection{Project Management Plan}

The Project Management Plan, described in the 6 th edition of the PMBOK ${ }^{\circledR}$ Guide, is a single document that defines how a project is executed, monitored, and controlled, including subsidiary management plans and baselines (scope, schedule, and costs).

Each of these plans defines the respective policies, procedures, criteria, and scope of application, roles, responsibilities, and authorities.

Table 3 shows the documents that make up the Project Management Plan. As can be seen, the authors of this research have added the Sustainability Management Plan.

Table 3. Project Management Plan.

\begin{tabular}{|c|c|c|c|c|}
\hline Life-Cycle Stage & Process & Delive & & How Is It Managed ... ? \\
\hline \multirow[t]{3}{*}{ Planning } & \multirow[t]{3}{*}{$\begin{array}{l}\text { 4.2. Develop the } \\
\text { Project } \\
\text { Management Plan }\end{array}$} & \multirow[t]{2}{*}{$\begin{array}{l}\text { Subsidiary } \\
\text { Management } \\
\text { Plans }\end{array}$} & $\begin{array}{l}\text { 6th Edition } \\
\text { PMBOK }\end{array}$ & $\begin{array}{ll}\text { - } & \text { Scope Management Plan } \\
\text { - } & \text { Schedule Management Plan } \\
\text { - } & \text { Cost Management Plan } \\
\text { - } & \text { Quality Management Plan } \\
\text { - } & \text { Resource Management Plan } \\
\text { - } & \text { Communications Management Plan } \\
\text { - } & \text { Risk Management Plan } \\
\text { - } & \text { Procurement Management Plan } \\
\text { - } & \text { Stakeholder Engagement Plan }\end{array}$ \\
\hline & & & Extension & - $\quad$ Sustainability Management Plan \\
\hline & & $\begin{array}{c}\text { Baseline } \\
\text { (triple restriction) }\end{array}$ & & $\begin{array}{ll}\text { - } & \text { Scope Baseline } \\
\text { - } & \text { Schedule Baseline } \\
\text { - } & \text { Cost Baseline } \\
\text { - } & \text { (Performance Measurement Baseline) }\end{array}$ \\
\hline
\end{tabular}

Note: Own Elaboration. The authors of this research have added the "Sustainability Management Plan" as an extension to the list of subsidiary management plans.

The Sustainability Management Plan is the document that, among other issues, includes the sustainability indicators and processes, which will allow effective management of the project's sustainability from its planning to the closing stage.

\subsection{Evaluation Matrix Alternatives}

In the context of tools and techniques, within the process "Scope management plans," the analysis of alternatives by expert judgment is contemplated [31]. 
The purpose of this analysis is to find the best option among several possible alternatives. Normally, it consists of a first stage where a screening is carried out, according to compliance requirements (Table 4).

Table 4. Evaluation Matrix Alternatives According to Compliance Requirements.

\begin{tabular}{lcccc}
\hline & Alternative 1 & Alternative 2 & Alternative 3 & Alternative 4... \\
\hline Requirement 1 & $\sqrt{ }$ & $\sqrt{ }$ & $\sqrt{ }$ & $\sqrt{ }$ \\
Requirement 2 & $\mathrm{X}$ & $\sqrt{ }$ & $\sqrt{ }$ & $\sqrt{ }$ \\
Requirement 3 & $\sqrt{ }$ & $\sqrt{ }$ & $\mathrm{X}$ & $\sqrt{ }$ \\
Requirement 4 & $\sqrt{ }$ & $\sqrt{ }$ & $\sqrt{ }$ & $\mathrm{X}$ \\
\hline
\end{tabular}

Finally, in a second stage, the most optimal alternative is chosen from among all those selected in the previous phase, based on a list of desirable criteria. In this sense, one of the most accepted methodologies for its application in different problems involving decision making with multiple criteria is the fuzzy AHP [43], which also allows to reduce the implicit subjectivity that is present in human appraisals to build an objective and consistent distribution [44].

In summary, the result is a matrix of relative weights, which allows comparisons to be made between the different alternatives in order to choose the one with the greatest contribution or percentage in relation to the rest.

As mentioned above, this whole process is carried out through the judgment of experts, who adopt different roles and functions [45]:

- Decision maker: identifies and selects stakeholders, defines the necessary resources, and provides decision criteria.

- Judge: selects the panel of experts, describes the case, participates in the discussions, and makes the final decision report.

- Expert: is familiar with the subject, analyzes it, and makes quantitative and qualitative judgments about it.

In particular, the expert should analyze the consistency of the matrix using an indicator called "consistency ratio." If this indicator is less than or equal to 0.1 , the level of inconsistency is acceptable; otherwise, it is recommended that the expert revise his estimates [46].

The fuzzy analytic hierarchical multi-criteria (fuzzy AHP) uses the triangular numbers of the "Saaty Scale" (Table 5).

Table 5. Saaty's Scale for Relative Importance and its Correspondence with Triangular or Diffuse Numbers.

\begin{tabular}{cccc}
\hline Saaty's Scale & Definition Fuzzy & Description & Triangular Scale \\
\hline 1 & Equally important (Eq. Imp.) & $\begin{array}{c}\text { The two elements contribute } \\
\text { equally to the property or criterion }\end{array}$ \\
\hline 5 & Feakly important (W. imp.) & $\begin{array}{c}\text { The element is moderately more } \\
\text { important with respect to the other }\end{array}$ \\
\hline 7 & Strongly important (S. Imp.) & $\begin{array}{c}\text { The element is strongly more } \\
\text { important with respect to the other } \\
\text { very strong with respect to the other }\end{array}$ \\
\hline 9 & Absolutely Important (A. Imp.) & $\begin{array}{c}\text { The importance of the element is } \\
\text { extreme with respect to the other }\end{array}$ & $(4,5,6)$ \\
\hline
\end{tabular}

Note: Adapted from Mendoza et al. [46].

A correct evaluation of alternatives and, ultimately, the scope of the project, depends to a large extent on correctly understanding the requirements and expectations of the 
stakeholders. In that sense, to facilitate their validation, requirements should be concrete, measurable, and with the lowest possible degree of uncertainty [31].

In this sense, according to Doran [47], the definition of the project scope should be based on objective criteria, such as Specific, Measurable, Attainable, Realistic, and Tangible (SMART) in order to determine the outcome of the project from the subsidiary management plans and baselines. Finally, the creation of the Work Breakdown Structure (WBS) and the drafting of the WBS dictionary will provide the graphical breakdown of the work packages and scope, respectively.

Scope verification involves obtaining formal acceptance by stakeholders and reviewing and inspecting delivered products to ensure that they meet expectations.

Finally, it is worth mentioning that the incorporation of a framework that integrated, at first, the inclusion of abstract concepts through a model for the sustainability of the organization, with the praxis of a project and the virtual dimension of education, generated new knowledge that represented a range of opportunities not only for the University to transform itself favorably from the teaching sector but also to expand specific services on its present and future projects, for example, in this case, the academic programs [48].

\section{Materials and Methods}

The design used in this research was exploratory and descriptive, based on triangulation, i.e., information from different sources was contrasted [49]. In this sense, the analysis of documented information on sustainability and social responsibility was combined with references from project methodology and education.

It also had a quantitative approach when selecting the most suitable training program since numerical data were used to establish behavioral patterns and validate theories [50].

The overall purpose of this research paper was to plan an approach to a sustainable project framework for training a group of students in a formative approach and in the context of the project life cycle.

According to Silvius et al. [13], the best way to integrate sustainability or other criteria into a standard is to develop another instrument based on a model and establish equivalencies between them.

In this context, the planning was based on a sustainability model and implemented in a standard approach with a process focus, which facilitated the identification of equivalencies with the process groups of the 6th edition of the PMBOK ${ }^{\circledR}$ project management standard.

Based on the new outline generated, a Sustainability Management Plan structure was developed. In this context, and within the framework of scope management, the training proposal was selected using a multi-criteria method, and the graphic representation of the scope (WBS) and the WBS Dictionary were created.

This was all part of the Project Management Plan, which was used to plan the training proposal in the context of a project's life cycle.

Figure 8 illustrates the methodological process of this research.

Broadly speaking, the methodological scope comprised six distinct stages:

1. Development of an approach matrix for a project framework with a process approach based on a model for sustainability, instrumented in a standard approach, and the 49 $(+3)$ process groups of the 6 th edition of the $\mathrm{PMBOK}^{\circledR}$ project management standard.

2. Selection of a student training proposal in the context of project scope management.

3. Graphical determination of student training project scope management (WBS).

4. Generation of a Sustainability Management Plan structure.

5. Implementation of the Project Management Plan within the life cycle of the student training project.

6. Summary of project deliverables. 


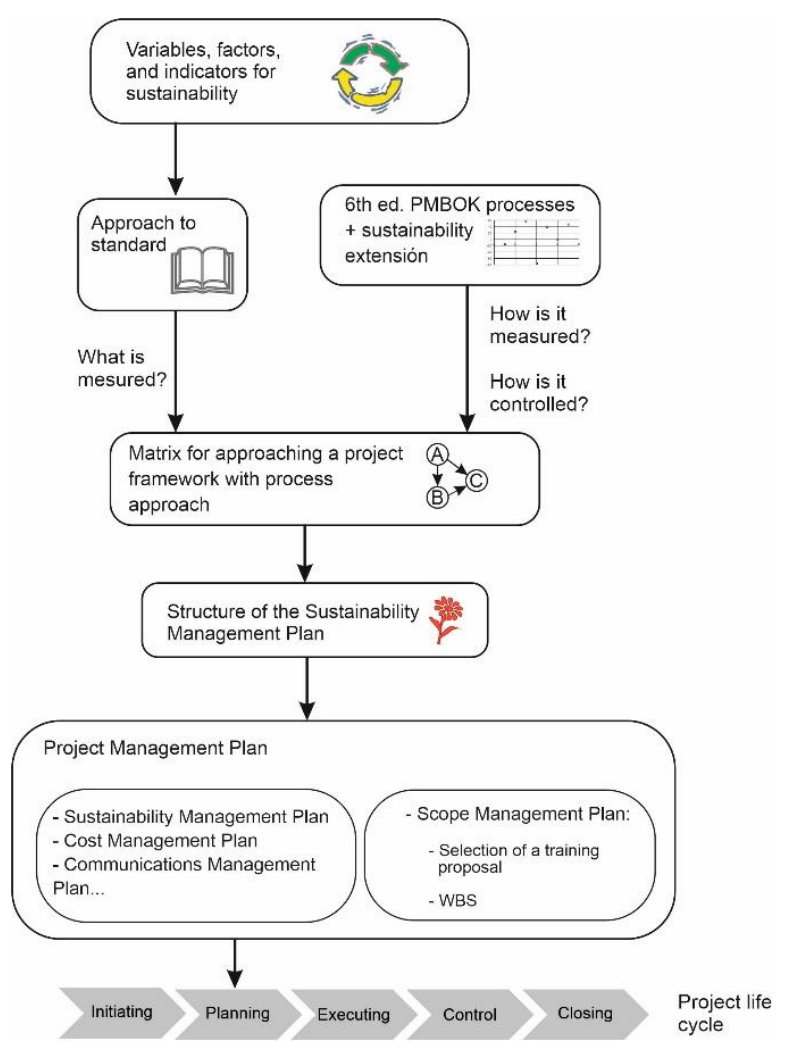

Figure 8. Methodological process followed in this research. Note: Own elaboration.

The panel of experts for point 1 consisted of a total of three professors from the University who teach in the postgraduate program in business administration and who participated in the discussions and filtering of the variables and indicators for sustainability.

The panel of experts for point 2 was also composed of three professors from the University's industrial organization and business administration degree program, who performed the calculations and determined the relative importance between the criteria and the alternatives, using an Excel spreadsheet adapted for this purpose:

- The selection of the training plans, allocation of resources, and definition of the decision criteria was carried out by a doctoral profile, professor of the Corporate Social Responsibility course of the Business Administration and Management degree.

- The selection of the group of experts was made by an IT doctoral profile.

- A doctoral candidate, professor of Statistics I, was in charge of performing the multicriteria analysis and issuing the results.

\section{Results}

\subsection{Obtaining Variables and Indicators for the Sustainability Model}

The variables of the model for sustainability as well as the bibliographic review of instruments and initiatives on social responsibility and sustainability, through expert judgment, and other documented information, are shown in Table 6.

From the point of view of their degree of linkage with social responsibility and sustainability, Table 7 shows the relationship between the different references.

The operationalization of variables to which the model was subjected resulted in a large number of sustainability indicators.

Table 8 shows some of the variables obtained and the corresponding sustainability factors and indicators. 
Table 6. Sustainability Model Variables and References Consulted.

\begin{tabular}{cc}
\hline Model Variables for Sustainability & References \\
\hline Responsible logistics and operations & {$[51]$} \\
\hline Sustainable resource management & {$[52]$} \\
\hline Environment & {$[51-56]$} \\
\hline Socially responsible people management and quality & {$[51-55,57,58]$} \\
\hline Socially Responsible Investment & {$[51,52,59]$} \\
\hline Sustainability culture and values & {$[54,55,59]$} \\
\hline Quality of products and/or services & {$[60,61]$} \\
\hline Corporate governance & {$[51,54,61]$} \\
\hline Community & {$[58,61]$} \\
\hline Socially responsible policy and strategy & {$[51,54,59,61]$} \\
\hline Sustainable leadership & {$[61]$} \\
\hline Governance & {$[61]$} \\
\hline Shareholders & {$[61]$} \\
\hline Suppliers and partners & {$[56,58,61,62]$} \\
\hline Clients, users, and consumers & {$[61,62]$} \\
\hline Communication (transversal) & {$[62]$} \\
\hline Information media & {$[62]$} \\
\hline
\end{tabular}

Note: Updated from García [23].

Table 7. Relationship Between the Different References.

\begin{tabular}{cc}
\hline Approach & Standard/Model \\
\hline Provide information on performance measurement performance & {$[51-54]$} \\
\hline Address some aspects of CSR and sustainability & {$[55-57,60]$} \\
\hline $\begin{array}{c}\text { Directly related to aspects of } \\
\text { social responsibility and sustainability }\end{array}$ & {$[58,61]$} \\
\hline Set guidelines directly or indirectly & {$[59,62]$} \\
\hline
\end{tabular}

Note: Own elaboration.

Table 8. Sustainability Variables, Factors, and Indicators.

\begin{tabular}{|c|c|c|}
\hline Variables & Factors & Sustainability Indicators \\
\hline 5.3. Governance & $\begin{array}{l}\text { 5.3.1. Good corporate } \\
\text { governance practices }\end{array}$ & $\begin{array}{c}\text { Capacity to comply with legislation, standards, and other } \\
\text { legal instruments, development of training programs on } \\
\text { corruption and bribery, incidence related to } \\
\text { dishonest practices }\end{array}$ \\
\hline \multirow{5}{*}{ 11.1. Environment } & $\begin{array}{l}\text { 11.1.1. Pollution prevention } \\
\text { and control }\end{array}$ & $\begin{array}{l}\text { Waste generation, gas emissions, fines and penalties, } \\
\text { legislative compliance }\end{array}$ \\
\hline & $\begin{array}{l}\text { 11.1.2. Environmental } \\
\text { risk management }\end{array}$ & $\begin{array}{l}\text { Hazard identification and risk assessment, level of hazard } \\
\text { perception, degree of accidentability, etc. }\end{array}$ \\
\hline & 11.1.3. Preservation of biodiversity & $\begin{array}{l}\text { Degree to which species and habitats are affected, } \\
\text { restoration of degraded environments, collaboration with } \\
\text { protection programs }\end{array}$ \\
\hline & 11.1.4. Fight against climate change & $\begin{array}{l}\text { Level of GHG emissions, adaptation and mitigation capacity } \\
\text { and costs, carbon footprint calculation }\end{array}$ \\
\hline & $\begin{array}{l}\text { 11.1.5. Life-cycle analysis of products } \\
\text { and/or services }\end{array}$ & $\begin{array}{l}\text { Implementation of the ISO } 14040 \text { series of standards, ability } \\
\text { to generate eco-labeled products, environmental impact } \\
\text { assessment, etc. }\end{array}$ \\
\hline
\end{tabular}


Table 8. Cont.

\begin{tabular}{|c|c|c|}
\hline Variables & Factors & Sustainability Indicators \\
\hline \multirow{8}{*}{$\begin{array}{l}\text { 11.2. Socially responsible } \\
\text { people management } \\
\text { and quality }\end{array}$} & $\begin{array}{l}\text { 11.2.1. Occupational health and } \\
\text { safety conditions }\end{array}$ & $\begin{array}{l}\text { Occupational health and safety management system, } \\
\text { accident rate, incident rate and occupational diseases, } \\
\text { legislative compliance capacity, fines and penalties. }\end{array}$ \\
\hline & $\begin{array}{l}\text { 11.2.2. Reconciliation of personal, } \\
\text { family, and work life }\end{array}$ & $\begin{array}{l}\text { Demographic, social, and economic characteristics of the } \\
\text { worker, ability to access work-life balance programs, and } \\
\text { level of satisfaction. }\end{array}$ \\
\hline & 11.2.3. Gender equity and equality & Degree of women's participation in governance tasks \\
\hline & 11.2.4. Conflict resolution & Degree of conflict generation within the organization \\
\hline & $\begin{array}{l}\text { 11.2.5. Diversity and } \\
\text { non-discrimination }\end{array}$ & $\begin{array}{c}\text { Ability to access diversity and non-discrimination programs, } \\
\text { level of access to employment for different groups, } \\
\text { especially people with disabilities }\end{array}$ \\
\hline & 11.2.6. Selection, hiring, and stability & Selection techniques, local labor \\
\hline & $\begin{array}{l}\text { 11.2.7. Education, training, } \\
\text { and competence }\end{array}$ & $\begin{array}{c}\text { Capacity to deliver training and awareness programs, costs } \\
\text { of programs, degree of follow-up }\end{array}$ \\
\hline & $\begin{array}{l}\text { 11.2.8. Internal communication and } \\
\text { employee participation }\end{array}$ & $\begin{array}{l}\text { Capacity to use internal communication tools, degree of } \\
\text { employee satisfaction with the channels and tools } \\
\text { established for internal communication }\end{array}$ \\
\hline \multirow[t]{2}{*}{ 11.3. Community } & $\begin{array}{l}\text { 11.3.1. Promotion of } \\
\text { local development }\end{array}$ & $\begin{array}{l}\text { Support for staff volunteer work, social management } \\
\text { programs, collaboration with NGOs, schools, health } \\
\text { consultants, and other local entities. Ability to hire local } \\
\text { labor. Investment in local suppliers }\end{array}$ \\
\hline & $\begin{array}{l}\text { 11.3.2. Preservation of traditions and } \\
\text { rights of indigenous communities }\end{array}$ & $\begin{array}{l}\text { Capacity to carry out social projects with indigenous } \\
\text { communities. Degree of incidence. Fines and sanctions }\end{array}$ \\
\hline $\begin{array}{l}\text { 11.4. Suppliers and } \\
\text { partners }\end{array}$ & $\begin{array}{l}\text { 11.4.1. Identification, evaluation, and } \\
\text { selection of suppliers and partners }\end{array}$ & $\begin{array}{l}\text { Ability to carry out supplier and partner diagnostics during } \\
\text { the follow-up stage, schedule courses, and other events on } \\
\text { sustainability for suppliers and partners }\end{array}$ \\
\hline
\end{tabular}

11.7.1. Communications with customers, users, and consumers

11.7. Communication

11.8. Socially responsible investment
11.7.2. Sustainability reports

11.7.3. Communication with suppliers and partners

11.8.1. Direct economic value generated and distributed

11.8.2. Direct economic value generated and not distributed

11.8.3. Economic value received, SRI
Ability to enable communication channels between the organization and customers, users, and consumers. Degree of satisfaction of clients, users, and consumers with the channels established for external communication

Ability to develop sustainability reports and enable public communication channels

Ability to develop communication channels between the organization and suppliers and partners. Degree of satisfaction of suppliers and partners with the channels established for external communication.

Social and labor benefits, tax payments, and distribution. Remuneration and working hours. Dividend distribution

Benefits retained by the organization. Investment in R\&D research

Investments, donations, and participation in social projects. Annual income and market value. Criteria in the policy of socially responsible investments and suitable investment values

Note: Own elaboration. The list of variables, factors, and indicators is not exhaustive. Only a few examples are provided here.

\subsection{Matrix for Approaching a Project Framework with Process Approach}

Table 9 relates the approach to the Standard, built from the instrumentalization of the model for sustainability, with the $49(+3)$ groups of processes. 
Table 9. Project Work Framework Approach Matrix.

\begin{tabular}{|c|c|c|}
\hline $\begin{array}{l}\text { Chapters Approximation to } \\
\text { Sustainability Standard }\end{array}$ & Variables/Factors/Indicators & $\begin{array}{l}\text { Processes of the } 6 \text { th Edition PMBOK }{ }^{\circledR}+ \\
\text { Processes Extension for Sustainability } \\
\qquad(49+3)\end{array}$ \\
\hline 1. Introduction & & 1. Introduction \\
\hline 2. Purpose and scope of application & & 1.2. Fundamental elements \\
\hline 3. Consultation documents & & - \\
\hline 4. Terms and definitions & & 1.1.2 Common vocabulary \\
\hline & - & $\begin{array}{l}\text { 1.5. The Project Life Cycle (Standard for } \\
\text { Project Management) }\end{array}$ \\
\hline & - & 4.1. Develop the project charter \\
\hline \multirow{3}{*}{ 5. Project Management Responsibility } & 5.1. Sustainability culture and Values & 14.2. Manage sustainability \\
\hline & 5.2. Social responsibility policy and strategy & 14.2. Manage sustainability \\
\hline & 5.3. Governance & 14.2. Manage sustainability \\
\hline 6. Leadership & 6.1. Sustainable leadership & 14.2. Manage sustainability \\
\hline \multirow{10}{*}{ 7. Planning } & \multirow{10}{*}{ 7.1. Planning } & 4.2. Develop the Project Management ${ }^{a}$ \\
\hline & & 5.2. Gather requirements \\
\hline & & 5.3. Define the scope \\
\hline & & 5.4. Create the WBS \\
\hline & & 6.2. Define the duration of activities \\
\hline & & 6.3. Sequence the duration of activities \\
\hline & & 6.4. Estimate the duration of activities \\
\hline & & 6.5. Develop the schedule \\
\hline & & 7.2. Estimate costs \\
\hline & & 7.3. Determine the budget \\
\hline \multirow[t]{2}{*}{ 8. Execution } & \multirow[t]{2}{*}{ 8.1. Execution } & $\begin{array}{l}\text { 4.3. Direct and manage the } \\
\text { implementation of the project }\end{array}$ \\
\hline & & 4.4. Manage project knowledge \\
\hline \multirow{5}{*}{ 9. Risks and opportunities } & \multirow{5}{*}{ 9.1. Risks and opportunities } & 11.2. Identify risks \\
\hline & & 11.3. Conduct qualitative risk analysis \\
\hline & & 11.4. Conduct quantitative risk analysis \\
\hline & & 11.5. Risk response planning \\
\hline & & 11.6. Implement Risk Response \\
\hline \multirow{2}{*}{ 10. Support } & 10.1. Information media & 10.2. Manage communications \\
\hline & 10.2. Documented information & 5.2. Gather requirements \\
\hline
\end{tabular}


Table 9. Cont.

\begin{tabular}{|c|c|c|}
\hline $\begin{array}{l}\text { Chapters Approximation to } \\
\text { Sustainability Standard }\end{array}$ & Variables/Factors/Indicators & $\begin{array}{l}\text { Processes of the 6th Edition } \text { PMBOK }^{\circledR}+ \\
\text { Processes Extension for Sustainability } \\
\qquad(49+3)\end{array}$ \\
\hline \multirow{16}{*}{ 11. Key issues for sustainability } & 11.1. Environment & 14.2. Manage sustainability \\
\hline & \multirow{4}{*}{$\begin{array}{l}\text { 11.2. Socially responsible people } \\
\text { management and quality }\end{array}$} & 9.2. Estimate resources for activities \\
\hline & & 9.3. Acquire resources \\
\hline & & 9.4. Develop the team \\
\hline & & 9.5. Lead the team \\
\hline & 11.3. Community & $\begin{array}{l}\text { 13.3. Manage stakeholder } \\
\text { engagement/participation }\end{array}$ \\
\hline & \multirow[b]{2}{*}{ 11.4. Suppliers and partners } & 13.1. Identify stakeholders \\
\hline & & $\begin{array}{l}\text { 13.3. Manage stakeholder } \\
\text { engagement/participation }\end{array}$ \\
\hline & \multirow[b]{2}{*}{ 11.5. Clients, users, and consumers } & 13.1. Identify stakeholders \\
\hline & & $\begin{array}{l}\text { 13.3. Manage stakeholder } \\
\text { engagement/participation }\end{array}$ \\
\hline & 11.6. Sustainable resource management & 9.2. Estimate resources for activities \\
\hline & 11.7. Communication & 10.2. Manage communications \\
\hline & 11.8. Socially responsible investment & 14.2. Manage sustainability \\
\hline & 11.9. Quality of products and/or services & 8.2. Quality management \\
\hline & 11.10. Shareholders & $\begin{array}{l}\text { 13.3. Manage stakeholder } \\
\text { engagement/participation }\end{array}$ \\
\hline & 11.11. Logistics and responsible operations & 12.2. Make acquisitions \\
\hline \multirow{4}{*}{ 12. Follow-up and control } & 12.1. Evaluation of legal compliance & \multirow{4}{*}{$\begin{array}{l}\text { 4.5. Monitor and control project work } b \\
\text { 4.6. Perform integrated change control } \\
\text { 5.5. Validate the scope }\end{array}$} \\
\hline & 12.2. Input information for review & \\
\hline & 12.3. Results of the review & \\
\hline & 12.4. Issuance of sustainability reports & \\
\hline 13. References and Annexes & $\begin{array}{l}\text { References to texts and other sustainability } \\
\text { management tools and projects }\end{array}$ & - \\
\hline
\end{tabular}

Note: Own elaboration. ${ }^{\mathrm{a}, \mathrm{b}}$ include everything related to management planning and control, respectively: the scope, schedule, cost, quality, resources, resources, communications, risk, procurement, stakeholder involvement, and sustainability.

\subsection{Selection of a Proposal for Student Training in the Context of Project Scope Management}

A total of seven training proposals were selected and were subject to the following compliance requirements:

- $\quad$ RC1: number of enrollment reservations over 150.

- RC2: face-to-face modality.

- RC3: official plan.

- RC4: bilingual format.

Table 10 shows the results.

As can be seen, the evaluation carried out by experts resulted in the selection of training plans $1,3,4,6$, and 7 .

The selected proposals were subjected to a fuzzy analytical hierarchical process (fuzzy AHP) based on five requirements gathered mostly by the UNE 66181 standard [63] for student satisfaction and expectations: accessibility, learning methodology, cost, maintainability, and employability. 
Table 10. Matrix of Compliance Requirements Evaluation.

\begin{tabular}{cccccccc}
\hline Requirements & P1 & P2 & P3 & P4 & P5 & P6 & P7 \\
\hline RC1 & $\sqrt{ }$ & $\sqrt{ }$ & $\sqrt{ }$ & $\sqrt{ }$ & $X$ & $\sqrt{ }$ & $\sqrt{ }$ \\
\hline RC2 & $\sqrt{ }$ & $X$ & $\sqrt{ }$ & $\sqrt{ }$ & $\sqrt{ }$ & $\sqrt{ }$ & $\sqrt{ }$ \\
\hline RC3 & $\sqrt{ }$ & $\sqrt{ }$ & $\sqrt{ }$ & $\sqrt{ }$ & $X$ & $\sqrt{ }$ & $\sqrt{ }$ \\
\hline RC4 & $\sqrt{ }$ & $\sqrt{ }$ & $\sqrt{ }$ & $\sqrt{ }$ & $\sqrt{ }$ & $\sqrt{ }$ & $\sqrt{ }$ \\
\hline
\end{tabular}

Note: P1, Advertising; P2, Environment; P3, Project Design, Management, and Evaluation; P4, Business; P5, Sports; P6, Marketing; P7, Communication.

Table 11 shows the criteria used and their description.

Table 11. Criteria Used in the Fuzzy Analytic Hierarchical Process (fuzzy AHP).

\begin{tabular}{cc}
\hline Criteria & Description \\
\hline Accessibility & $\begin{array}{r}\text { Ability of the training program to meet the student's accessibility needs } \\
\text { and expectations due to digital divide issues, disabilities, etc. }\end{array}$ \\
\hline $\begin{array}{c}\text { Learning methodology } \\
\text { Cost }\end{array}$ & $\begin{array}{r}\text { Ability for the training program to efficiently find solutions to complex } \\
\text { problems based on analysis and in the context of } \\
\text { methodological planning. }\end{array}$ \\
\hline Maintainability & Potential ability for the training program to be modified, expanded, etc. \\
\hline Employability & Ability of the training program to facilitate entry into the labor market \\
\hline Note: Own elaboration. &
\end{tabular}

Table 12 shows the results of the criteria comparison matrix. The last column expresses the priority vector of the criteria. It could be observed that there was a greater preference for employability $(45.5 \%)$, learning methodology $(24.5 \%)$, and cost $(14.3 \%)$ versus program maintenance $(8.3 \%)$ and accessibility $(7.4 \%)$.

Table 12. Criteria Comparison Matrix.

\begin{tabular}{cccccc}
\hline Criteria & & Fuzzy Weight & & Weighting & Normalized \\
\hline Accessibility & 0.050423 & 0.072716177 & 0.115315 & 0.079485 & $\mathbf{0 . 0 7 4}$ \\
\hline Learning methodology & 0.144423 & 0.243026718 & 0.401551 & 0.263 & $\mathbf{0 . 2 4 5}$ \\
\hline Cost & 0.087791 & 0.141423855 & 0.230631 & 0.153282 & 0.089345 \\
\hline Maintainability & 0.054726 & 0.080846236 & 0.132462 & 0.489262 & $\mathbf{0 . 0 8 3}$ \\
\hline Employability & 0.288845 & 0.461987015 & 0.716954 & Total & $\mathbf{0 . 4 5 5}$ \\
\hline
\end{tabular}

Note: Own elaboration.

In order to determine that there are no contradictions between preferences, the consistency relationship must be found. To do this, first of all, the consistency index is found:

$$
\mathrm{CI}=\frac{\lambda_{\max }-\mathrm{n}}{\mathrm{n}-1}
$$

where $\lambda_{\max }$ is the sum of the products obtained between the criteria comparison matrix (A) and the vector of weights $(\mathrm{W})$, and $\mathrm{n}$ is the number of criteria.

Next, we must determine the random consistency, RI:

$$
\mathrm{RI}=\mathrm{IA} * \frac{\mathrm{n}-2}{\mathrm{n}}
$$


where IA is a constant that is determined by the number of criteria, according to Table 13.

Table 13. IA Constant Values According to the Number of Criteria.

\begin{tabular}{ccccccccccc}
\hline $\mathbf{n}$ & $\mathbf{1}$ & $\mathbf{2}$ & $\mathbf{3}$ & $\mathbf{4}$ & $\mathbf{5}$ & $\mathbf{6}$ & $\mathbf{7}$ & $\mathbf{8}$ & $\mathbf{9}$ \\
\hline IA & 0 & 0 & 0.52 & 0.89 & 1.11 & 1.25 & 1.35 & 1.40 & 1.45 \\
\hline
\end{tabular}

Note: Adapted from Saaty [64].

Finally, the consistency ratio, $\mathrm{CR}$, is found as the quotient between the consistency index and the random consistency:

$$
\mathrm{CR}=\frac{\mathrm{CI}}{\mathrm{RI}}
$$

If $\mathrm{CR}<0.1$ is met, it means that it has been reasonably weighted.

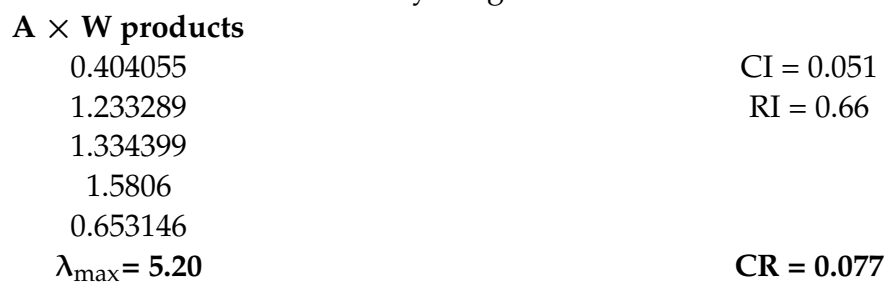

After checking the consistency of the weighting $(C R=0.077<0.1)$, the next step was to find the decision matrix. To this end, a priority vector of alternatives was found according to each criterion, and these results were then weighted with those obtained in the previous criteria weighting matrix. In this way, the final decision matrix or vector of priority of alternatives was obtained (Table 14).

Table 14. Decision matrix.

\begin{tabular}{cccccc}
\hline Criteria & P1 & P3 & P4 & P6 & P7 \\
\hline Learning methodology & 0.027149 & 0.003814 & 0.027149 & 0.010884 & 0.004988 \\
\hline Employability & 0.082421 & 0.020159 & 0.110327 & 0.01514 & 0.016747 \\
\hline Accessibility & 0.021136 & 0.054727 & 0.054727 & 0.007905 & 0.004176 \\
\hline Maintainability & 0.011347 & 0.036923 & 0.027595 & 0.002406 & 0.004889 \\
\hline Cost & 0.078875 & 0.285135 & 0.031566 & 0.031566 & 0.028251 \\
\hline TOTAL & 0.220928 & 0.400758 & 0.251363 & 0.0679 & 0.059052 \\
\hline Rank & $\mathbf{3}$ & $\mathbf{1}$ & $\mathbf{2}$ & $\mathbf{4}$ & $\mathbf{5}$ \\
\hline
\end{tabular}

Note: Own elaboration

It can be seen that the choice of the most appropriate training plan corresponds to P3: Design, Management, and Evaluation of Projects, with 40.1\%; followed by P4: Business, with 25\%; and P1: Advertising, with 22.1\%. At a greater distance are the Marketing (P6) and Communication (P7) plans, with $6.8 \%$ and $6 \%$ of importance, respectively.

\subsection{Graphical Scoping for the Student Training Proposal (WBS)}

Figure A1 in Appendix A illustrates the most representative work packages (basically up to level two) for the project proposal for training students in Project Management and Evaluation in a Higher Education Institution.

\subsection{Sustainability Management Plan Structure}

The structure of the Sustainability Management Plan is shown in Table 15. 
Table 15. Structure of the Sustainability Management Plan.

\section{Mission}

Provide quality education to meet the educational needs of the people

\section{Vision}

Become an institution of reference for its teaching methodology based on sustainability

3. Values

Sustainability, commitment, good teaching practices

4. Objective

Train 180 students in a program in Project Design, Management, and Evaluation.

\section{Scope of the project \\ Logistics area \\ Technical-legal area \\ Organizational area \\ Training area}

Comprehensive project management

\section{HEI Sustainability Policy}

The training project for students must be aligned with the sustainability indicators required by the Educational Institution and in accordance with the base guidelines of scope, costs, and schedule.

\section{Sustainability objectives}

Identify and assess possible negative impacts of the student training project.

Establish preventive and corrective measures to eliminate or minimize the negative impacts of the student training project.

\section{Stages}

8.1. Initiating

8.2. Sustainability Management Planning

\section{Necessary procedures}

Prepare the training project constitution act Identify stakeholders

Develop the Project Management Plan

Estimating baselines (time, costs, etc.)

Develop the budget for the training project

Estimate procurement

Impart teaching methodology

Evaluate training

Manage communications

Control changes

8.4. Monitoring and control

Conduct student satisfaction surveys

Elaborate sustainability reports

\subsection{Closing}

9. Roles and responsibilities

10. Sustainability tools and techniques

11. Sustainability metrics
Close the project

Assignment of the Project Manager and the project teamLevels of authority Regulations, cost-benefit analysis, simulations, mapping process, flowcharts, etc.

Set of performance indicators for sustainability

As can be seen, the plan includes the measurements to be made for the training of students and how they should be carried out and monitored for each of the WBS work packages described.

\subsection{Implementation of the Project Management Plan within the Life Cycle of the Student Training}

Figure A2 in Appendix A illustrates the baseline components involved in the planning process for the student training proposal, while Figure A3 illustrates the remaining stages and the operation of the change control.

\subsection{Summary of Deliverables of the Sustainable Capacity Building Project}

Table 16 shows the deliverables of the sustainable training project. 
Table 16. Summary of Sustainable Capacity Building Project Deliverables.

\begin{tabular}{|c|c|c|}
\hline Work Packages & Deliverables & Description \\
\hline \multirow{5}{*}{$\begin{array}{l}\text { 1. Integrated Project } \\
\text { Management }\end{array}$} & 1.1. Initiation & $\begin{array}{l}\text { Document of the Project Charter and identification of } \\
\text { stakeholders }\end{array}$ \\
\hline & $\begin{array}{l}\text { 1.2. Development of the Project } \\
\text { Management Plan }\end{array}$ & $\begin{array}{l}\text { Document containing the different subsidiary } \\
\text { management plans (scope, costs, schedule, etc.) } \\
\text { and baselines }\end{array}$ \\
\hline & 1.3. Project execution & $\begin{array}{l}\text { Reports with data resulting from the execution of the } \\
\text { different management plans }\end{array}$ \\
\hline & 1.4. Project Control & $\begin{array}{l}\text { Document in which change requests, acceptances, } \\
\text { rejections, etc. are recorded }\end{array}$ \\
\hline & 1.5. Closure and completion of the project & $\begin{array}{l}\text { Plan with the proposal to train students in Project } \\
\text { Design, Management, and Leadership. }\end{array}$ \\
\hline \multirow{7}{*}{ 2. Logistics } & 2.1. Development of baselines & $\begin{array}{l}\text { Document that includes the schedule, duration of the } \\
\text { training, budget. etc. }\end{array}$ \\
\hline & 2.2. Classroom conditioning & $\begin{array}{l}\text { Document that includes the space selected for the } \\
\text { teaching, environmental conditions, lighting, } \\
\text { ergonomics, visualization screens, cleanliness, etc. }\end{array}$ \\
\hline & 2.3. Accessibility conditions & $\begin{array}{l}\text { Document with the conditions of access to the } \\
\text { building and the classroom, architectural barriers, } \\
\text { access for the disabled, etc. }\end{array}$ \\
\hline & 2.4. Contracting suppliers & $\begin{array}{l}\text { Contracts with certified suppliers, best } \\
\text { management practices }\end{array}$ \\
\hline & 2.5. Student management & $\begin{array}{l}\text { Document with the plan for recruitment, selection } \\
\text { and registration of students, administrative } \\
\text { information, and other student services }\end{array}$ \\
\hline & 2.6. Supply of didactic material & $\begin{array}{l}\text { Document with the inventory of didactic material to } \\
\text { be offered to students for follow-up training }\end{array}$ \\
\hline & 2.7. Procurement management & $\begin{array}{l}\text { Document with the purchasing matrix necessary to } \\
\text { carry out the training }\end{array}$ \\
\hline \multirow{5}{*}{ 3. Technical-legal } & $\begin{array}{l}\text { 3.1. Identification of legislation, regulations, } \\
\text { and other legal requirements }\end{array}$ & $\begin{array}{c}\text { Legislative and regulatory requirements necessary to } \\
\text { deliver training }\end{array}$ \\
\hline & $\begin{array}{l}\text { 3.2. Identification of environmental and } \\
\text { social aspects and impacts }\end{array}$ & $\begin{array}{c}\text { Forecast of positive and negative aspects (causes) } \\
\text { and impacts (consequences) that may affect } \\
\text { sustainability during all stages of the } \\
\text { training process }\end{array}$ \\
\hline & 3.3. Risk identification & $\begin{array}{l}\text { Document with the risks that could affect the } \\
\text { development of the training, for example, regarding } \\
\text { time, scope and schedule, cost overruns, lack of } \\
\text { attendance, incompetent teachers, etc. }\end{array}$ \\
\hline & $\begin{array}{l}\text { 3.4. Development of printed and } \\
\text { digital materials }\end{array}$ & $\begin{array}{l}\text { Theoretical contents, practical activities, library, } \\
\text { multimedia, and other didactic resources }\end{array}$ \\
\hline & 3.5. Development of adapted materials & Contents adapted for people with disabilities \\
\hline \multirow{3}{*}{ 4. Organizational } & 4.1. Stakeholder awareness raising & $\begin{array}{l}\text { Document that compiles the actions taken by the } \\
\text { University to raise awareness of the importance of } \\
\text { sustainability among students, internal staff, and the } \\
\text { general public (brochures, posters, bulletin boards, } \\
\text { conferences, courses, etc.) }\end{array}$ \\
\hline & 4.2. Organization of human resources & $\begin{array}{l}\text { Document with the selection of teachers and their } \\
\text { assignments, functions of administrative and service } \\
\text { personnel, board of directors, etc. }\end{array}$ \\
\hline & 4.3. Results orientation & $\begin{array}{l}\text { Diagnosis to determine the degree of closeness of the } \\
\text { institution with respect to the training objectives }\end{array}$ \\
\hline \multirow[t]{2}{*}{ 5. Training } & $\begin{array}{l}\text { 5.1. Development of the teaching } \\
\text { methodology }\end{array}$ & $\begin{array}{l}\text { Document that includes the teaching methodology, } \\
\text { description of contents, objectives, competencies, } \\
\text { scope, evaluation system, etc. }\end{array}$ \\
\hline & 5.2. Development of the evaluation & $\begin{array}{l}\text { Theoretical and practical evaluation tests, } \\
\text { competency measurement, training assessment } \\
\text { surveys, etc. }\end{array}$ \\
\hline
\end{tabular}




\section{Discussion}

The measurement of sustainability in a project must be based on performance indicators (what is measured), resources (what is measured with), and processes (how it is measured and controlled). This is something complex to carry out since, among other things, project standards and methodologies do not include a Sustainability Management Plan as part of the development of the Project Management Plan.

In relation to determining a set of performance indicators for sustainability, the models analyzed showed the lack of a base of measurement indicators. This means that the standards and instruments for sustainability are theoretical and incomplete. The results are corroborated by Rodriguez et al. [23] and Gonzalez et al. [24], who point to the great dispersion between models and the difficulty and subjectivity of measuring social and environmental aspects compared to those of an economic nature as causes of the problem. Other authors, such as Raducanu [65], refer to the GRI [54] as a reference point for the contribution of sustainability indicators but always in a complementary manner and not integrated into the strategic guidelines of the organization [5]. In this sense, we consider that a holistic view of sustainability is very important in order to build measurement instruments aligned with the strategic and operational vision of the company and that generate value to the organization through processes, as made explicit in the 7th edition of the PMBOK ${ }^{\circledR}$ Guide [12].

With regard to the review of key words on sustainability in the $\mathrm{PMBOK}^{\circledR}$ project management standards (6th and 7th editions), ICB4 ${ }^{\circledR}$-IPMA and ISO 21500:2012, it was observed that there was a lack of explicit references. In this regard, the term "responsibility" was found on the order of twenty times in each of the standards analyzed, while the words "sustainability" and "ethics" appeared on the order of fifteen times in ICB4 ${ }^{\circledR}$-IPMA and $\mathrm{PMBOK}^{\circledR}$ (6th edition), respectively. No major differences were found between the old and the new version of PMBOK ${ }^{\circledR}$. On the other hand, in ISO 21500:2012, hardly any explicit references to sustainability terms were found, with the exception of the term "Responsibility." This shows that the integration of sustainability is something that is not yet recognized in project management [13]. Some authors, such as Uribe et al. [6], gave stakeholders as an example, mentioning that, although the concept has been handled from the perspective of risk management in projects, a set of practices to adequately satisfy them from a social responsibility model that contributes to generate, in addition, long-term relationships (sustainability) have not been described. In this line, some authors, such as Paneque et al. [37], considered that the incorporation of sustainable criteria in the IPMA ICB $4{ }^{\circledR}$ standard is an important boost for the integration of sustainability in the di-rection and management of projects while explicitly recognizing the compe-tence of directors in the performance of their profession. We believe that it is important that organizations that issue norms and standards for project management and direction increasingly take into account the integration of sustainability in their successive versions and publications, which should be done through standards and cover all stages of the project life cycle. This statement is consistent with the work of Paneque et al. [37], who recommended using these terms in all areas of competence and to continuously review the strategy so as not to forget the sustainability objectives as the project develops.

In relation to the approach to a project framework with a process approach, the result obtained was an equivalence matrix between the standard approach, based on continuous improvement and integrating the performance indicators for sustainability with the process groups of the PMBOK Guide 6th edition (+3). In this context, it was possible to establish relationships with all the indicators, which confirmed the good degree of integration between both "standards." This is corroborated by Silvius et al. [13], who stated in their work that the best way to integrate some sustainable or other criteria into a standard is to develop another instrument from a model and establish equivalences between them. In this context, we believe that it is important to develop new holistic frameworks that consider what is being measured and how it is being measured and monitored as opposed to traditional standards. 
In order to select the training proposal within the framework of project scope management, the multi-criteria fuzzy AHP methodology was used. The chosen alternative corresponded to training in Project Design, Management, and Leadership, based on several criteria. This methodology is widely used since it reduces the imprecision or subjectivity of human judgment [66]. In addition, it was found that employability was the most valued by the panel of experts $(45.5 \%)$, followed by the training teaching methodology $(24.5 \%)$. This demonstrates the growing importance of project management in the world of work. In particular, the Project Manager is a profession on the rise [67], whose salary increases by about $28 \%$ for a PMI-certified manager relative to a non-certified one [68].

Based on the project framework, and in the context of scope management, the Work Breakdown Structure (WBS) was created. The result was the breakdown of the work packages into functional areas or level-1 deliverables: integrated project management, logistical, technical-legal, organizational, and training. These packages were further divided into level-2 deliverables. The graphical interpretation of the scope clarified the work and its dissemination to stakeholders as well as the identification of risks that may occur at different stages of the training project. This is corroborated by Brotherton et al. [69], who considered the WBS as a planning tool that plays a fundamental role in project decision making and change control.

The creation of the WBS facilitated the structuring of the Sustainability Management Plan. The result was a document integrated in the Project Management Plan, which contained the aspects to be measured (indicators) and the procedures for their measurement and control (processes) in the context of planning. This plan contemplated the guidelines for incorporating sustainability criteria throughout each and every phase of the life cycle of the student training project. However, some authors, such as Vanega [70], considered that each of the life cycle phases contributes differently to sustainability; however, the planning phase has the greatest potential to determine sustainability at a lower cost.

\section{Conclusions}

Throughout the research, it has been found that:

- Corporate Social Responsibility (CSR) refers to the present and to past situations, issuing periodic reports on its actions, while sustainability refers to the future evolution and durability of its actions over time.

- The models and instruments for CSR and sustainability are generally theoretical and incomplete, lacking a basis of measurement indicators and not integrated into the organization's strategic guidelines.

- There are very few explicit references to sustainability in the $\mathrm{PMBOK}^{\circledR}$ (6th edition), ICB4 ${ }^{\circledR}$-IPMA, and ISO 21500:2012 standards, so it is important to improve this aspect and to integrate them in the best possible way in project management.

- It is possible to obtain an equivalence matrix between a standard approach based on continuous improvement and integrating the performance indicators for sustainability, with the process groups of the PMBOK Guide 6th edition (+3). In this context, it was possible to establish relationships with all indicators, which confirmed the good degree of integration between both "standards."

- The multi-criteria fuzzy AHP methodology is suitable for selecting an alternative from among several since it reduces the imprecision or subjectivity of human judgment in relation to other traditional methods, such as AHP.

- Employability and methodology are two of the most important aspects when selecting a course for training students in Project Design, Management, and Leadership. In particular, training in this subject provides a high degree of employability, which increases with the possibility of certification.

- The breakdown of the work packages into functional areas (WBS): integrated project management, logistics, technical-legal, organizational and training, clarifies the work, facilitates dissemination to stakeholders and the identification of training project risks. 
The Sustainability Management Plan is not generally found among the subsidiary plans, so it must be added to the Project Management Plan and applied throughout each and every phase of the student training project life cycle.

\section{Limitations}

This research has some limitations, for example, this study could be extended to other stages of the project life cycle outside of planning. In addition, a detailed risk analysis could be carried out to determine the possible threats, damages, and consequences that could result from the training course. It would also be interesting to study other factors, and not only the number of enrollment requests, in order to study in depth the preferences of the students at the time of taking a training course. This limitation could be overcome by conducting interviews and collecting data through surveys.

Author Contributions: Conceptualization, S.G.V. and R.M.Á.; data curation, E.G.V. and S.G.V.; formal analysis, E.G.V.; investigation, R.M.Á.; project administration, E.G.V. and I.D.N.; resources, L.A.D.L. and R.M.Á.; software, I.D.N. and J.L.V.M.; supervision, S.G.V.; validation, E.G.V., S.G.V. and R.M.Á.; visualization, J.L.V.M.; writing—original draft, E.G.V.; writing—review and editing, S.G.V. All authors have read and agreed to the published version of the manuscript.

Funding: This research is part of European Project Erasmus + Lovedistance (Reference: 609949EPP-1-2019-1-PTEPPKA2-CBHE-JP), funded by SODERCAN (Society for Regional Development of Cantabria), in conjunction with CITICAN (Investigation and Technology Centre of Cantabria).

Institutional Review Board Statement: Not applicable.

Informed Consent Statement: Informed consent was obtained from all subjects involved in the study.

Data Availability Statement: The data presented in this study are available on request from the corresponding author. The data are not publicly available due to the conditions of the project contract with the funder (Society for Regional Development of Cantabria).

Acknowledgments: The authors would like to thank to the Centro de Investigación y Tecnología Industrial de Cantabria (CITICAN) and the Universidad Europea del Atlántico for their valuable collaboration.

Conflicts of Interest: The authors declare no conflict of interest. 


\section{Appendix A}

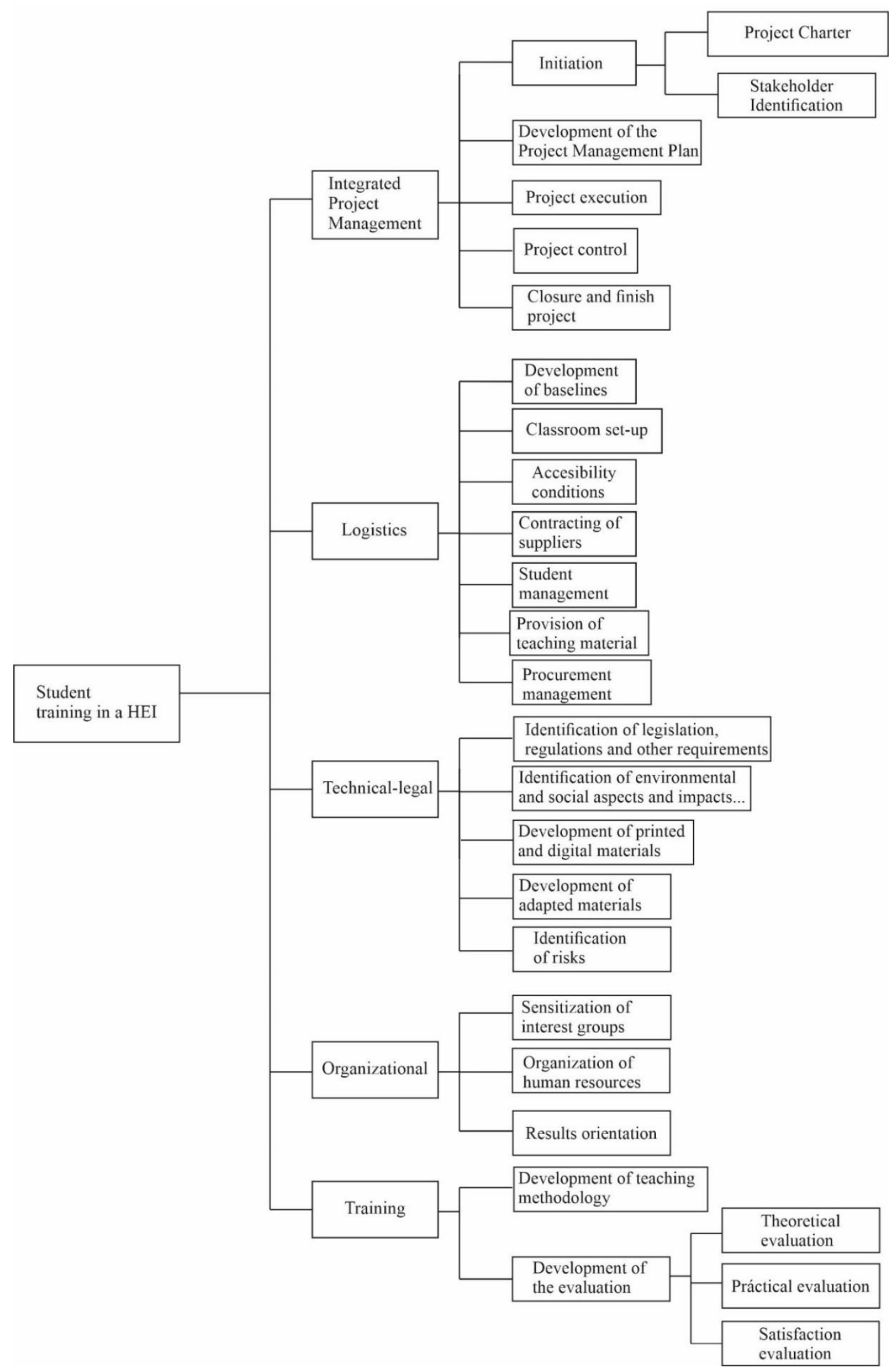

Figure A1. WBS work packages for the student training project. Note: Own elaboration. 


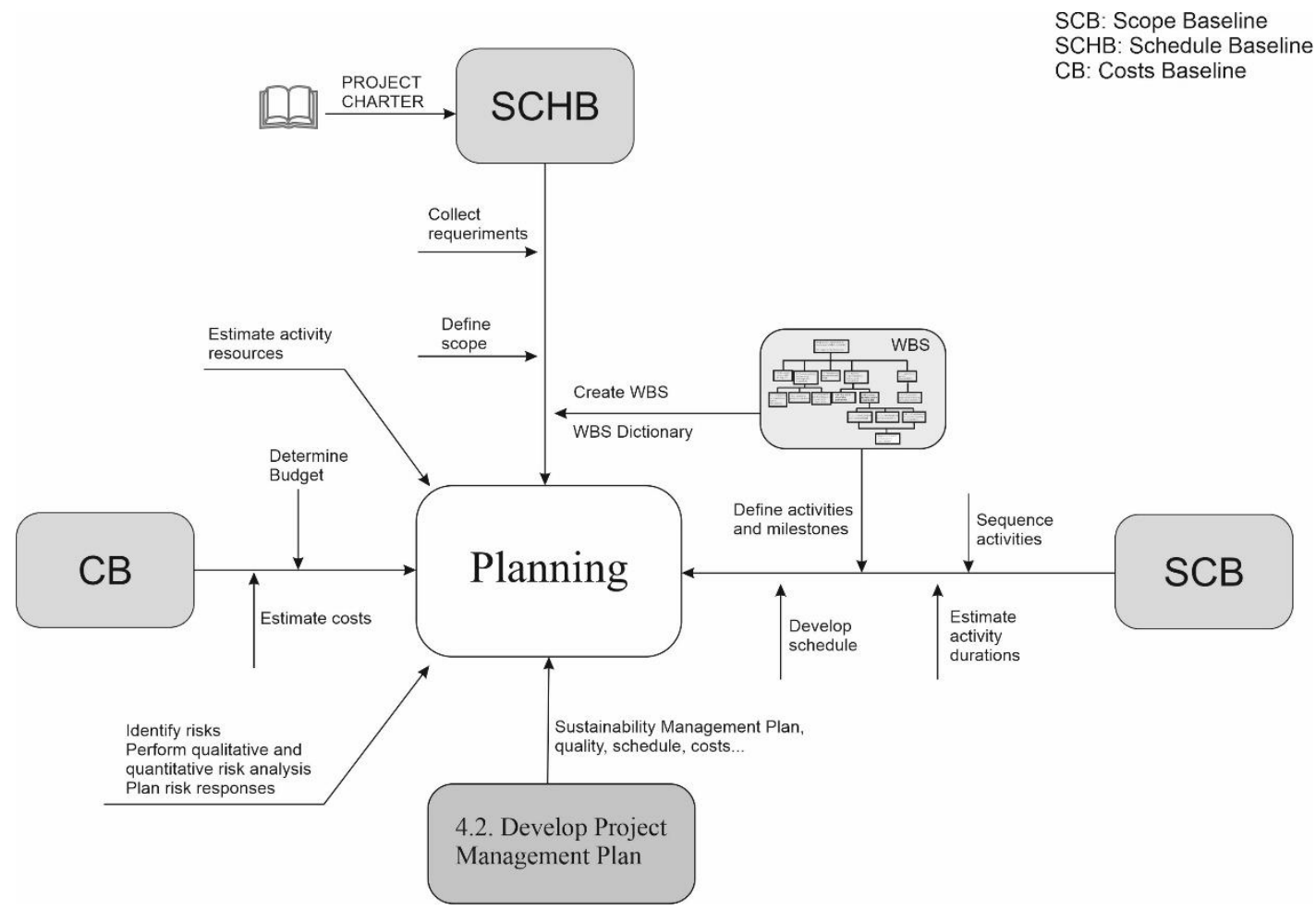

Figure A2. Planning process of the student training proposal in a context defined by sustainability criteria. Note: Own elaboration.

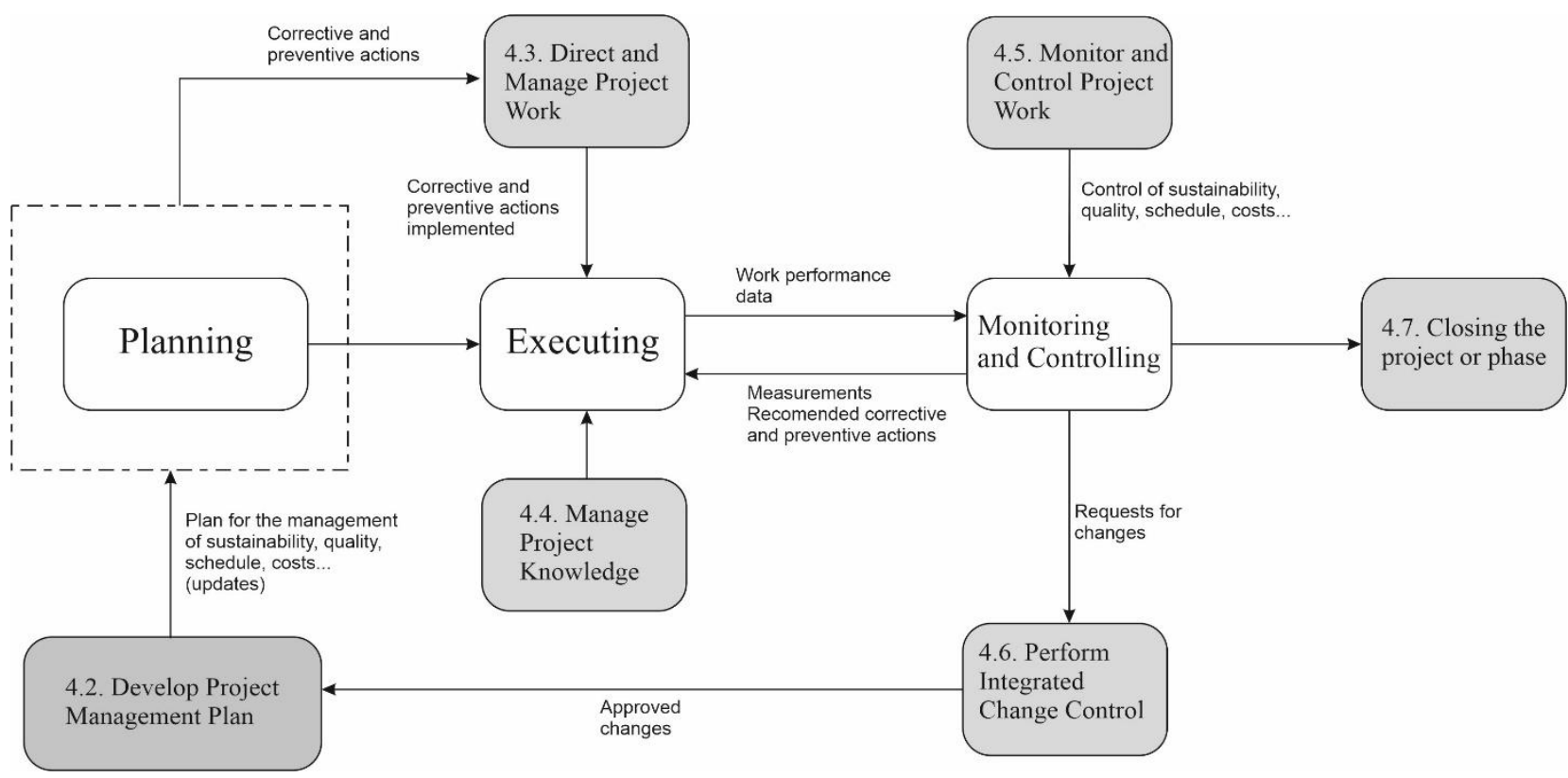

Figure A3. Execution and Monitoring and Control Stages of the proposal for training students in a context defined by sustainability criteria. Note: Own elaboration.

\section{References}

1. World Commission on Environment and Development. Our Common Future; Oxford University Press: Oxford, UK, 1987. Available online: https://sustainabledevelopment.un.org/content/documents/5987our-common-future.pdf (accessed on 14 September 2021).

2. Kidd, C. The evolution of sustainability. J. Agric. Environ. Ethics 1992, 5, 1-26. [CrossRef] 
3. Marín, S. Sostenibilidad y RSC. In Cuadernos de la Cátedra Caixa Bank de Responsabilidad Social Corporativa; Universidad de Navarra, IESE Business School: Navarra, Spain, 2019. Available online: https://media.iese.edu/research/pdfs/ST-0514.pdf (accessed on 14 September 2021).

4. Waddock, S.A.; Bodwell, C.; Graves, S.B. Responsibility: The new business imperative. Acad. Manag. Exec. 2002, 16, 132-149. [CrossRef]

5. Sánchez Sumelzo, N. La Sostenibilidad en el Sector Empresarial: Importancia de los Distintos Grupos de Interés en el Proceso de Cambio a Sostenibilidad en el Sector Empresarial [Internet] [Proyecto Final de Máster]; UPC, Institut Universitari de Recerca en Ciència i Tecnologies de la Sostenibilitat: Barcelona, Spain, 2012. Available online: http:/ /hdl.handle.net/2099.1/18820 (accessed on 18 August 2021).

6. Uribe, M.E.; Vargas, O.A.; Merchán, L. La responsabilidad social empresarial y la sostenibilidad, criterios habilitantes en la gerencia de proyectos. Entramado 2017, 14, 52-63. [CrossRef]

7. Andreu, A.; Fernández, J.L. De la RSC a la sostenibilidad corporativa: Una evolución necesaria para la creación de valor. Harv.-Deusto Bus. Rev. 2011, 207, 5-21. Available online: https://www.researchgate.net/publication/297757785_De_la_RSC_a_ la_sostenibilidad_corporativa_una_evolucion_necesaria_para_la_creacion_de_valor (accessed on 18 August 2021).

8. Ministerio de Derechos Sociales y Agenda 2030. Claves Empresariales de la Nueva Estrategia de Desarrollo 2030. 2021. Available online: https:/ / www.agenda2030.gob.es/recursos/docs/informe-progreso21-eds-2030.pdf (accessed on 18 August 2021).

9. Padickakudy, M. Evaluating the Importance of Sustainability in the Project Management Process. [Tesis de Máster Inédita]. 2019. Available online: https:/ / www.pma.at/files/downloads/625/master-thesis-padickakudy-.pdf (accessed on 18 August 2021).

10. UNESCO. Replantear la Educación ¿Hacia un Bien Común Mundial? J. Supranatl. Policies Educ. (JoSPoE) 2015, 4, 207-209. Available online: https:/ / revistas.uam.es/jospoe/article/view/5678 (accessed on 18 August 2021).

11. Obradović, V. Model Upravljanja Promenama Primenom Metodologije Projektnog Menadžmenta. Ph.D. Thesis, Faculty of Organizational Sciences, University of Belgrade, Belgrade, Serbia, 2010.

12. Project Management Institute. A Guide to the Project Management Body of Knowledge (PMBOK®Guide), 7th ed.; Project Management Institute: Newton Square, PA, USA, 2021.

13. Silvius, G.; Schipper, R.; Planko, J.; van den Brink, J.; Köhler, A. Sustainability in Project Management [Online]; Routledge Ltd.: Great Britain, UK, 2017. Available online: https://www.taylorfrancis.com/books/e/9781351896573 (accessed on 18 August 2021).

14. Brent, A.; Labuschagne, C. Sustainable life cycle management: Indicators to assess the sustainability of engineering projects and technologies. IEEE Int. Eng. Manag. Conf. 2004, 1, 99-103. [CrossRef]

15. Morfaw, J. Fundamentals of project sustainability. In Proceedings of the PMI®Global Congress 2014, Phoenix, AZ, USA, 25-28 October 2014.

16. Thiele, L.P. Sustainability, 2nd ed.; Polity Press: Cambridge, UK, 2016.

17. Tasdemir, C.; Gazo, R.; Quesada, H.J. Sustainability benchmarking tool (SBT): Theoretical and conceptual model proposition of a composite framework. Environ. Dev. Sustain. 2020, 22, 6755-6797. [CrossRef]

18. Rodríguez, J.; Reguant, M. Calcular la fiabilidad de un cuestionario o escala mediante el SPSS: El coeficiente alfa de Cronbach. REIRE Rev. D'innovació Recer. Educ. 2020, 13, 1-13. [CrossRef]

19. Alva, A. Operacionalización de las Variables, s.f. Available online: http:// cmapspublic2.ihmc.us/rid=1177276915826_1221648340 _5171/operacionalizacion.pdf (accessed on 18 August 2021).

20. Sanchís, J.R. La Responsabilidad Social Empresarial no es Suficiente. 2019. Available online: https://www.eldiario.es/ alternativaseconomicas / responsabilidad-social-empresarial-suficiente_132_1229154.html (accessed on 18 August 2021).

21. Kramer, M.R.; Porter, M. Creating shared value. Harv. Bus. Rev. 2011, 89, 62-77.

22. Marcelino, S.; Pérez, A.; González, L.F. Using project management as away to sustainability. From a comprehensive review to a framework definition. J. Clean. Prod. 2015, 99, 1-16. [CrossRef]

23. Rodríguez, S.; Arco, M.L.; López, M.V.; Rodríguez, L. Where Does CSR Come from and Where Does It Go? A Review of the State of the Art. Adm. Sci. 2020, 10, 60. [CrossRef]

24. González, M.; Donate, M.; Guadamillas, F. Propuesta de una escala para la medición de la responsabilidad social corporativa = A proposal for the measurement of corporate social responsibility. Pecvnia Rev. Fac. Cienc. Econ. Empresariales 2014, 18, 1-18. [CrossRef]

25. Ríos, G. La Agenda 2030 y la Responsabilidad Social Empresarial; Organización Iberoamericana de Seguridad Social: Madrid, Spain, 2020.

26. Fernández, R. Responsabilidad Social de la Empresa. Su introducción. Rev. Ecosostenible 2007, 34, 30-50.

27. International Organization of Standardization. Guía de Responsabilidad Social ISO 26000. 2010. Available online: https: //www.iso.org/files/live/sites/isoorg/files/store/sp/PUB100258_sp.pdf (accessed on 18 August 2021).

28. García, E. Elaboración de un Modelo y Aproximación a Una Norma de Gestión Empresarial Para la Implantación de la RSC en la Organización [Tesis de Doctorado no Publicada]; Universidad Politécnica de Catalunya: Barcelona, Spain, 2010.

29. Toljaga-Nikolić, D.; Todorović, M.; Dobrota, M.; Obradović, T.; Obradović, V. Project Management and Sustainability: Playing Trick or Treat with the Planet. Sustainability 2020, 12, 8619. [CrossRef]

30. Salcedo, L.; Porto, A.; Gutiérrez, C.; Agudelo, J.; Moreno-Ortiz, C. Responsabilidad Social Empresarial: Modelo de procesos de desarrollo de productos con base en la Metodología PRiSM y la Estrategia P5. Prod. + Limpia 2016, 11, 111-125. [CrossRef] 
31. Project Management Institute. A Guide to the Project Management Body of Knowledge (PMBOK®Guide), 6th ed.; PMI: Newton Square, PA, USA, 2017.

32. International Organization of Standardization. Orientación Sobre Gestión de Proyectos ISO 21500; International Organization of Standardization: Geneva, Switzerland, 2012.

33. International Project Management Association. ICB—IPMA Competence Baseline, Version 4.0; International Project Management Association: Nijkerk, The Netherland, 2015.

34. Vukomanovic, M.; Young, M.; Huynink, S. IPMA ICB 4.0-A global standard for project, programme and portfolio management competences. Int. J. Proj. Manag. 2016, 34, 1703-1705. [CrossRef]

35. Piza-Flores, V.; Aparicio, J.L.; Rodríguez, C.; Beltrán, J. Transversalidad del eje "Medio ambiente” en educación superior: Un diagnóstico de la Licenciatura en Contaduría de la UAGro. RIDE Revista Iberoamericana Para la Investigación y el Desarrollo Educativo 2018, 8, 598-621. [CrossRef]

36. Okland, A. Gap analysis for incorporating sustainability in project management. Procedia Comput. Sci. 2015, 64, 103-109. [CrossRef]

37. Paneque, A.; Bastante, M.J.; Capuz, S. Analysis of aspects and principles related to sustainability in IPMA ICB4. In Proceedings of the 21th International Congress on Project Management and Engineering, Cádiz, Spain, 12-17 July 2017.

38. Sabini, L.; Muzio, D.; Alderman, N. 25 years of "sustainable projects". What we know and what the literature says. Int. J. Proj. Manag. 2019, 37, 820-838. [CrossRef]

39. Kivilä, J.; Martinsuo, M.; Vuorinen, L. Sustainable project management through project control in infrastructure projects. Int. J. Proj. Manag. 2017, 35, 1167-1183. [CrossRef]

40. Bravo, B.; Dzul, L.; Gracia, S.; Fernández, F. Coordinación entre los niveles de gestión de proyectos: Portafolio, programa y proyecto. Dyna 2009, 84, 421-428. Available online: https:/ / www.revistadyna.com/busqueda/coordinacion-entre-niveles-degestion-de-proyectos-portafolio-programa-y-proyecto (accessed on 18 August 2021).

41. Project Management Institute. The Standard for Program Management, 4th ed.; PMI: Newton Square, PA, USA, 2017.

42. Project Management Institute. The Standard for Portafolio Management, 4th ed.; PMI: Newton Square, PA, USA, 2017.

43. Escandón López, J.; Parra, C.; Osorio, J. Metodología multicriterio para la selección de proveedores bajo consideraciones de riesgo. Sci. Tech. 2019, 24, 232-239. [CrossRef]

44. Mayor, J.; Botero, S.; González, J. Modelo de decisión multicriterio difuso para la selección de contratistas en proyectos de infraestructura: Caso Colombia. Obras Proy. 2016, 20, 56-74. [CrossRef]

45. Rosqvist, T. On the Use of Expert Judgement in the Qualification of Risk Assessment, 1st ed.; VTT Publications: Espoo, Finland, 2003; pp. 14-18.

46. Mendoza, A.; Solano, C.; Palencia, D.; García, D. Aplicación del proceso de jerarquía analítica (AHP) para la toma de decisión con juicio de expertos. Rev. Chil. Ing. 2018, 27, 348-360. Available online: https://scielo.conicyt.cl/pdf/ingeniare/v27n3/0718-3305 -ingeniare-27-03-00348.pdf (accessed on 18 August 2021). [CrossRef]

47. Doran, G. There's a S. M. A. R. T. Way to Write Management Goals and Objectives. Manag. Rev. (AMA Forum) 1981, $70,35-36$.

48. García, A.; Gracia, S.; Estay, C.; Cisteró, J.; Fernández, J.; Álvarez, A. Metodología de enseñanza-aprendizaje en diseño de proyectos de ingeniería. Afinidad 2007, 64, 456-463.

49. Soler, P.; Enrique, A.M. Reflexión sobre el rigor científico en la investigación cualitativa. Estudios sobre el Mensaje Periodístico 2012 18, 879-888. Available online: http:/ / revistas.ucm.es/index.php/ESMP/article/view/40966 (accessed on 18 August 2021).

50. Sampieri, R.; Collado, C.; Baptista, P. Metodología de la Investigación, 5th ed.; McGraw-Hill: New York, NY, USA, 1997. Available online: https:/ / www.uv.mx/personal/cbustamante/files/2011/06/Metodologia-de-la-Investigaci\%C3\%83\%C2\%B3n_Sampieri. pdf (accessed on 18 August 2021).

51. Alianza Empresarial para el Desarrollo de Costa Rica. Política de Sostenibilidad en la Cadena de Valor AED. 2017. Available online: https: / / www.aedcr.com/recurso/publicaciones/politica-de-sostenibilidad-en-la-cadena-de-valor-aed (accessed on 18 August 2021).

52. Responsabilitat Social a Catalunya, Recursos Sobre els Objectius de Desenvolupament Sostenible (ODS). 2017. Available online: https://treball.gencat.cat/web/.content/13_-_consell_relacions_laborals/Coneixeu_nos/Activitat/Jornada_Eines_RS_ setembre2018/GUIA_CATALA.pdf (accessed on 18 August 2021).

53. Cerrejón Minería Responsable. Informe de Sostenibilidad. 2017. Available online: https://www.cerrejon.com/wp-content/ uploads/informes/informe\%20de\%20sostenibilidad\%202020.pdf (accessed on 18 August 2021).

54. Global Reporting Initiative. Sustainability Reporting Guidelines. G4; Global Reporting Initiative: Amsterdam, The Netherlands, 2013. Available online: https://www.globalreporting.org/resourcelibrary/GRIG4-Part1-Reporting-Principles-and-StandardDisclosures.pdf (accessed on 18 August 2021).

55. United Nations. Pacto Mundial de Naciones Unidas. Una Llamada a la Acción Para Empresas Sostenibles. 2018. Available online: https:/ / www.pactomundial.org/wp-content/uploads/2018/02/Flyer-New-Strategy-GC-2018_20180126.pdf (accessed on 18 August 2021).

56. International Organization of Standardization. Environmental Management Systems ISO 14001; International Organization of Standardization: Geneva, Switzerland, 2015.

57. International Organization of Standardization. Occupational Health and Safety Management Systems-Requirements with Guidance for Use ISO 45001; International Organization of Standardization: Geneva, Switzerland, 2018. 
58. SAI. Social Accountability International SA8000; SAI: New York, NY, USA, 2008.

59. International Organization of Standardization. Guindance on Social Responsibility ISO 26000; International Organization of Standardization: Geneva, Switzerland, 2010.

60. International Organization of Standardization. Quality Management Systems ISO 9001; International Organization of Standardization: Geneva, Switzerland, 2015.

61. Forética. SGE 21. Sistema de Gestión Ética y Socialmente Responsible. 2017. Available online: https://foretica.org/sge21/ (accessed on 18 August 2021).

62. AccountAbility. Assuring Credibility in Reporting on Progress toward Sustainability Goals AA1000AS v3. 2018. Available online: https: / www.accountability.org/standards / (accessed on 29 September 2021).

63. UNE. Normalización Española. Gestión de la Calidad. Calidad de la Formación Virtual UNE 66181. 2012. Available online: https: / / www.une.org/encuentra-tu-norma/busca-tu-norma/norma?c=N0049661 (accessed on 29 September 2021).

64. Saaty, T. Toma de Decisiones Para Líderes; RWS Publications: Pittsburgh, PA, USA, 1997.

65. Raducanu, E. Memorias Sostenibles GRI: Análisis de la Información Publicada por Empresas Españolas. Master's Thesis, Universitat Jaume I, Valencia, Spain, 2017.

66. Herrera, M.F.; Osorio, J.C. Modelo para la gestión de proveedores utilizando AHP difuso. Estud. Gerenc. 2006, 99, 69-88. Available online: https:/ / www.icesi.edu.co/revistas/index.php/estudios_gerenciales/article/view/190/188 (accessed on 29 September 2021).

67. Alexander, M. What Is a Project Manager? The Lead Role for Project Success. 2021. Available online: https:/ /www.cio.com/ article/3224865/what-is-a-project-manager-the-lead-role-for-project-success.html (accessed on 18 August 2021).

68. Invensis. Global Learning Services (n.d). Available online: https://www.invensislearning.com/info/pmi-acp-job-opportunities (accessed on 18 August 2021).

69. Brotherton, S.A.; Fried, R.T.; Norman, E.S. Applying the work breakdown structure to the project management lifecycle. In Proceedings of the PMI®Global Congress 2008-North America, Denver, CO, USA, 19 October 2008.

70. Vanega, J.A. ¿Cómo incorporar los criterios y principios de la sostenibilidad en el diseño, construcción y gestión de infraestructuras? Ekon. Rev. Vasca Econ. 2006, 63, 88-111. Available online: https://dialnet.unirioja.es/servlet/articulo?codigo=2326281 (accessed on 18 August 2021). 